Article

\title{
Fluorescent Bis(guanidine) Copper Complexes as Precursors for Hydroxylation Catalysis ${ }^{+}$
}

\author{
Florian Strassl ${ }^{1}{ }^{\circledR}$, Alexander Hoffmann ${ }^{1}$, Benjamin Grimm-Lebsanft ${ }^{2} \oplus$, Dieter Rukser ${ }^{2}$, \\ Florian Biebl ${ }^{2}$, Mai Anh Tran ${ }^{1}$, Fabian Metz ${ }^{1}$, Michael Rübhausen ${ }^{2}$ and \\ Sonja Herres-Pawlis $1, *$ (D) \\ 1 Institute of Inorganic Chemistry, RWTH Aachen University, Landoltweg 1, 52074 Aachen, Germany; \\ florian.strassl@ac.rwth-aachen.de (F.S.); alexander.hoffmann@ac.rwth-aachen.de (A.H.); \\ mai.anh.tran@rwth-aachen.de (M.A.T.); fabian.metz@rwth-aachen.de (F.M.) \\ 2 Institut für Nanostruktur- und Festkörperphysik, Universität Hamburg and Center For Free Electron Laser \\ Science, Notkestrasse 85, 22607 Hamburg, Germany; benjamin.lebsanft@physik.uni-hamburg.de (B.G.-L.); \\ dieter.rukser@physnet.uni-hamburg.de (D.R.); fbiebl@physnet.uni-hamburg.de (F.B.); \\ ruebhausen@physnet.uni-hamburg.de (M.R.) \\ * Correspondence: sonja.herres-pawlis@ac.rwth-aachen.de; Tel.: +49-241-80-93902 \\ + Dedicated to Prof. Dr. Gerald Henkel on the occasion of his 70th birthday.
}

Received: 5 August 2018; Accepted: 15 October 2018; Published: 20 October 2018

\begin{abstract}
Bis(guanidine) copper complexes are known for their ability to activate dioxygen Unfortunately, until now, no bis(guanidine) copper-dioxygen adduct has been able to transfer oxygen to substrates. Using an aromatic backbone, fluorescence properties can be added to the copper(I) complex which renders them useful for later reaction monitoring. The novel bis(guanidine) ligand $\mathrm{DMEG}_{2}$ tol stabilizes copper(I) and copper(II) complexes (characterized by single crystal X-ray diffraction, IR spectroscopy, and mass spectrometry) and, after oxygen activation, bis( $\mu$-oxido) dicopper(III) complexes which have been characterized by low-temperature UV/Vis and Raman spectroscopy. These bis(guanidine) stabilized bis( $\mu$-oxido) complexes are able to mediate tyrosinase-like hydroxylation activity as first examples of bis(guanidine) stabilized complexes. The experimental study is accompanied by density functional theory calculations which highlight the special role of the different guanidine donors.
\end{abstract}

Keywords: oxygen activation; guanidine; copper complexes; crystallography; UV/Vis spectroscopy; hydroxylation; $\mathrm{N}$-donor ligand; density functional theory

\section{Introduction}

A major topic in bioinorganic chemistry is the analysis, reproduction, and, ultimately, the improvement of the active sites of natural catalytic systems. This study focuses on dioxygenactivating copper complexes, mimicking the enzyme tyrosinase. Relatively, dioxygen itself is an inert molecule and usually has to be activated by selected enzymes [1]. Such enzymes like tyrosinase are biological oxygenation catalysts [2]. Tyrosinase is a type III copper enzyme, that catalyzes the ortho-hydroxylation of the amino acid tyrosine via the corresponding catechol as an intermediate to the subsequent quinone upon further oxidation $[3,4]$. These reactions are also responsible for the formation of melanin and other pigments in human or animal skin. Tyrosinase consists of a dicopper center that forms a peroxido complex when it reacts with dioxygen [5-10].

Over recent years, many groups have developed model systems to mimic the efficient tyrosinase enzyme [11-16]. Instead of histidines, other N-donor groups are utilized, such as imidazoles [17-20], imines [4,21-24], and pyrazoles $[4,19,25,26]$. Even though in protein systems only the peroxido species 
have been observed by X-ray crystallography and Raman spectroscopy [5-7], Tolman and coworkers discovered the bis( $\mu$-oxido) species of a dicopper complex as another stable intermediate [27]. Both species are discussed for their reactivity since they exist in many cases in an equilibrium at low temperatures $[28,29]$. Stack et al. used simple imidazole ligands and observed a peroxide complex formed by self-assembly at $-125^{\circ} \mathrm{C}$ [17]. They later found a bis( $\mu$-oxido) dicopper(III) intermediate prior to a hydroxylation reaction, which was supported by DFT (density functional theory) calculations [20].

If a stable peroxido or bis( $\mu$-oxido) species is obtained, usually the next step involves testing the activity of the reaction system in the hydroxylation of substrates. Workgroups with major advancements in synthesizing catalytically active model systems are Tuczek et al. $[4,18,23,30,31]$, Lumb and Ottenwaelder et al. [32-34], Casella et al. [10,35,36], and Herres-Pawlis et al. [19,25,37,38]. Tuczek et al. developed tyrosinase model systems based on pyridine-imines [18,39]. They also investigated the differences in activity of mono- and binucleating ligands [30] and introduced the most efficient catalyst for phenolic conversion in terms of the turnover number (TON) [21]. The aerobic oxygenation of phenolic substrates with subsequent reactivity patterns mediated by the simple DBED/Cu system was studied by Lumb and Ottenwaelder et al. [32,33]. Using more complicated benzimidazole ligands, the group of Casella introduced a monophenolase reaction with a dinuclear peroxido dicopper complex [40]. They successfully investigated the hydroxylation of ortho-phenolates and phenols $[36,41]$. The group of Herres-Pawlis et al. presented efficient hydroxylation catalysis with bis(pyrazoly)methane copper complexes $[19,25]$. Recently a room-temperature stable bis(pyrazolyl) (pyridinyl)methane copper complex, proved to be the fastest catalyst in such an environment [38].

Many metal complexes with different applications are derived from guanidines since the guanidine unit is one of the strongest $\mathrm{N}$-donors [42]. As mentioned earlier, $\mathrm{Cu}_{2} \mathrm{O}_{2}$ species are mostly stable as peroxido or bis( $\mu$-oxido) species, in parallel, tris(guanidines) have been reported to form stable (superoxido)copper(II) species [43-45]. Dinuclear tetrakis(guanidine)copper complexes are active catalysts in redox reactions [46-48].

Guanidines are also found in other applications apart from oxygen activation. For the atom transfer radical polymerization (ATRP), hybrid (guanidine)copper complexes presented a strong activity [49]. Copper guanidinoquinoline complexes have been analyzed to progress the understanding of the entatic state $[50,51]$. A very versatile class of guanidine ligands are bis(guanidine) ligands [52]. They consist of the two building blocks of a chloroformamidinium chloride (Vilsmeier salt) and a diamine (as a spacer unit). Herres-Pawlis et al. showed that through combining different guanidine and spacer units, a whole library of successful synthesized bis(guanidines) is possible [53]. Copper(I) complexes of bis(guanidines) form bis( $\mu$-oxido)copper(III) structures with dioxygen at low temperatures $[9,52,54]$. The $\mathrm{Cu}_{2} \mathrm{O}_{2}$ intermediate species are usually not very stable after oxygenation and decay to a bis( $\mu$-hydroxido)copper(II) and a bis( $\mu$-alkoxido)-bridged dinuclear copper(II) complex in equal amounts, as shown for [ $\mathrm{Cu}(\mathrm{btmgp}) \mathrm{I}]$ [55]. An exceptionally stable $\mathrm{Cu}_{2} \mathrm{O}_{2}$ complex was stabilized by a sterically demanding bis(guanidine) ligand. This species was stable for days and analyzed by Raman and extended X-ray absorption fine structure spectroscopy [52]. Although aromatic bis(guanidines) were mentioned only once as being able to form $\mathrm{Cu}_{2} \mathrm{O}_{2}$ species [56], they were already reported to be active for the ATRP of styrene [57].

An ongoing research topic for copper complexes is the analysis of bubbly flows [58]. Under the background of bubbly flows, it is essential to have a reaction system that reacts in a multiphase environment and can be analyzed with different in-situ spectroscopy methods. The bis(guanidine) copper complex [Cu(btmgp)I] system is suitable for analyses with UV/Vis spectroscopy [59] and displays a strong color change [60]. Therefore, it has been reported in several studies [55,61,62]. It was also analyzed by fluorescence spectroscopy but showed only a weak signal [63]. The copper complexes of the ligand $\mathrm{TMG}_{2}$ tol improved the fluorescence by introducing an aromatic unit into the spacer of the bis(guanidine) [56]. The aim of this work is to introduce an aromatic bis(guanidine) copper complex that forms $\mathrm{Cu}_{2} \mathrm{O}_{2}$ species, is active for hydroxylation reactions, and is highly fluorescent. 


\section{Results}

The ligand bis(dimethylethyleneguanidino)toluene (DMEG 2 tol) was synthesized by the standard procedure described by Herres-Pawlis et al. based on the studies of Kantlehner et al. [62,64]. The dimethylethylenechloroformamidinium chloride (Vilsmeier salt) was added to the aromatic amine (2-amino-benzyl)amine and after two deprotonation steps the bis(guanidine) ligand was formed, see Scheme 1.
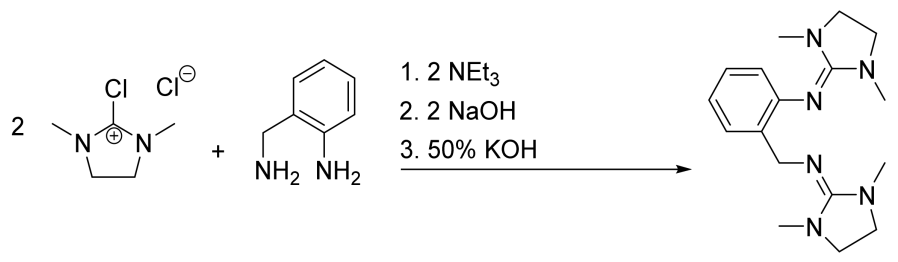

Scheme 1. Synthesis of the $\mathrm{DMEG}_{2}$ tol ligand in acetonitrile.

The copper salts $\mathrm{CuI}, \mathrm{CuBr}, \mathrm{CuCl}, \mathrm{CuCl}_{2},\left[\mathrm{Cu}(\mathrm{MeCN})_{4}\right](\mathrm{OTf})$, and $\left[\mathrm{Cu}(\mathrm{MeCN})_{4}\right]\left(\mathrm{PF}_{6}\right)$ were added to the ligand $\mathrm{DMEG}_{2}$ tol (L1) to obtain the copper complexes $\left[\mathrm{Cu}\left(\mathrm{DMEG}_{2}\right.\right.$ tol)I] (C1), $\left[\mathrm{Cu}\left(\mathrm{DMEG}_{2}\right.\right.$ tol $\left.) \mathrm{Br}\right](\mathrm{C} 2),\left[\mathrm{Cu}\left(\mathrm{DMEG}_{2}\right.\right.$ tol $\left.) \mathrm{Cl}\right](\mathrm{C} 3),\left[\mathrm{Cu}\left(\mathrm{DMEG}_{2}\right.\right.$ tol $\left.) \mathrm{Cl}_{2}\right](\mathrm{C} 4),\left[\mathrm{Cu}\left(\mathrm{DMEG}_{2} \text { tol }\right)\right]_{2}(\mathrm{OTf})_{2}$ (C5), and $\left[\mathrm{Cu}\left(\mathrm{DMEG}_{2} \mathrm{tol}\right)\right]_{2}\left(\mathrm{PF}_{6}\right)_{2}(\mathrm{C} 6)$, respectively, see Scheme 2.

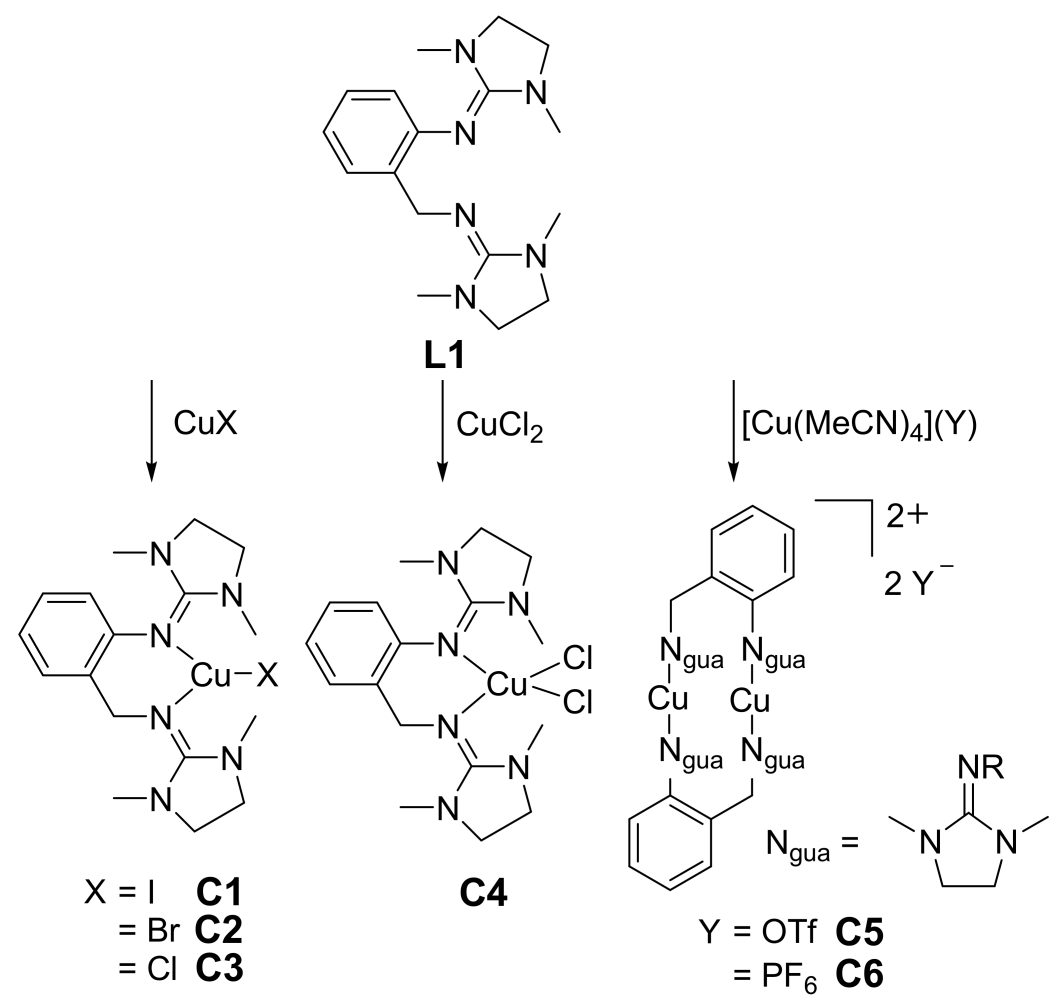

Scheme 2. Synthesis of the copper complexes C1-C4, by adding the copper salts $\mathrm{CuI}$ (for $\mathbf{C 1}$ ), $\mathrm{CuBr}$ (for $\mathrm{C2}$ ), $\mathrm{CuCl}$ (for $\mathrm{C} 3$ ), and $\mathrm{CuCl}_{2}$ (for $\mathbf{C 4}$ ) to the ligand $\mathbf{L 1}$. Adding the copper salts $\left[\mathrm{Cu}(\mathrm{MeCN})_{4}\right](\mathrm{OTf}$ ) and $\left[\mathrm{Cu}(\mathrm{MeCN})_{4}\right]\left(\mathrm{PF}_{6}\right)$ with weakly coordinating anion results in the formation of complexes $\mathbf{C 5}$ and $\mathbf{C 6}$.

Single crystals for complexes C1-C5 were obtained by slow-cooling of acetonitrile or tetrahydrofuran solutions which were heated up beforehand or by gas-phase diffusion of diethyl ether. All complexes were analyzed by IR spectroscopy and mass spectrometry. The molecular structures of the complexes in the solid state were determined by single-crystal X-ray diffraction. The crystals obtained for complex $\mathbf{C 6}$ were not suitable for single-crystal X-ray diffraction. 


\subsection{Molecular Structures in the Solid State}

The molecular structures in the solid state of the complexes C1-C4 and the cationic unit of $\mathbf{C 5}$ are shown in Figure 1. The complexes C1-C4 consist of the DMEG 2 tol ligand that coordinates the central copper atom with the corresponding halide.

$\left[\mathrm{Cu}\left(\mathrm{DMEG}_{2}\right.\right.$ tol)l] $(\mathbf{C} 1)$

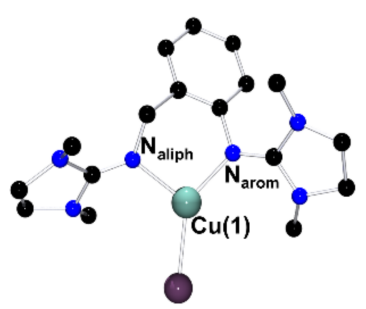

$\left[\mathrm{Cu}\left(\mathrm{DMEG}_{2} \mathrm{tol}\right) \mathrm{Cl}_{2}\right](\mathrm{C} 4)$

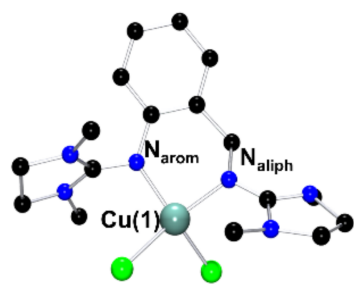

[Cu(DMEG 2 tol)Br] (C2)

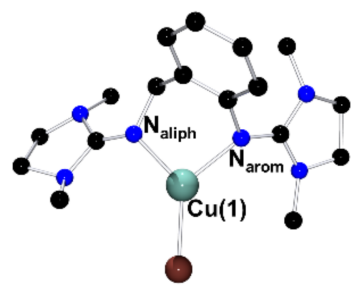

[Cu(DMEG ${ }_{2}$ tol $\left.) \mathrm{Cl}\right](\mathbf{C} 3)$

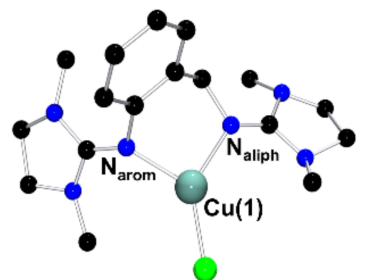

$\left[\mathrm{Cu}\left(\mathrm{DMEG}_{2} \text { tol }\right)\right]_{2}(\mathrm{OTf})_{2}(\mathrm{C5})$

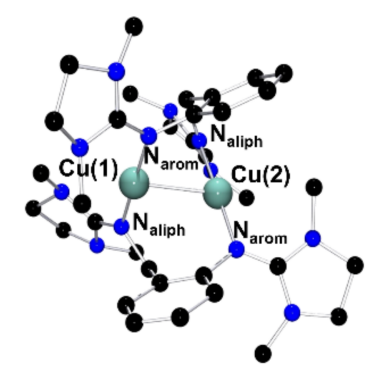

Figure 1. Molecular structures of the complexes C1-C4 and the cationic unit of complex C5 in the solid state (hydrogen atoms are omitted for clarity).

In the structure of complex $\mathbf{C 5}$, a dinuclear dicationic, see Figure 1, unit is present where two ligands each coordinate with their guanidine moieties' two copper atoms. Selected values of the molecular structures, determined by X-ray diffraction are listed in Table 1, for the crystallographic data see Table 3.

Table 1. Selected bond length $[\AA]$, angles $\left[^{\circ}\right]$ and key parameters of complexes C1-C5.

\begin{tabular}{|c|c|c|c|c|c|}
\hline & $\mathrm{C} 1$ & $\mathrm{C} 2$ & $\mathrm{C} 3$ & $\mathrm{C} 4$ & $\mathrm{C} 5$ \\
\hline $\mathrm{Cu}(1)-\mathrm{N}_{\text {gua,aliph }}$ & $2.058(5)$ & $2.025(2)$ & $2.013(3)$ & $1.963(2)$ & $1.887(2)$ \\
\hline $\mathrm{Cu}(2)-\mathrm{N}_{\text {gua,aliph }}$ & - & - & - & - & $1.878(2)$ \\
\hline $\mathrm{Cu}(1)-\mathrm{N}_{\text {gua,arom }}$ & $1.992(4)$ & $2.082(2)$ & $2.097(3)$ & $1.989(2)$ & $1.893(2)$ \\
\hline $\mathrm{Cu}(2)-\mathrm{N}_{\text {gua,arom }}$ & - & - & - & - & $1.885(2)$ \\
\hline $\mathrm{Cu}-\mathrm{X}^{[\mathrm{a}]}$ & $2.476(1)$ & $2.327(1)$ & $2.200(1)$ & $2.260(1) / 2.251(1)$ & - \\
\hline $\mathrm{Cu}(1) \ldots \mathrm{Cu}(2)$ & - & - & - & - & $2.732(1)$ \\
\hline $\mathrm{N}-\mathrm{Cu}(1)-\mathrm{N}$ & $97.5(1)$ & $95.4(1)$ & $94.8(2)$ & $92.6(1)$ & 178.1(1) \\
\hline $\mathrm{N}-\mathrm{Cu}(2)-\mathrm{N}$ & - & - & - & - & 178.9(1) \\
\hline$\tau_{4}[\mathrm{~b}]$ & - & - & - & 0.55 & - \\
\hline$\varrho\left(\text { gua }_{\text {aliph }}\right)^{[c]}$ & 0.94 & 0.94 & 0.94 & 0.97 & 0.96 \\
\hline$\varrho(\text { gua arom })^{[\mathrm{c}]}$ & 0.97 & 0.96 & 0.96 & 1.00 & 0.98 \\
\hline Guanidine twist $\left(\text { gua }_{\text {aliph }}\right)^{[d]}$ & 16.2 & 17.8 & 17.6 & 16.6 & 16.8 \\
\hline Guanidine twist (gua arom) ${ }^{[d]}$ & 12.7 & 12.8 & 12.6 & 6.4 & 12.7 \\
\hline
\end{tabular}

${ }^{[\mathrm{a}]} \mathrm{X}=\mathrm{I}(\mathbf{C} 1), \mathrm{Br}(\mathbf{C} 2), \mathrm{Cl}(\mathbf{C} 3), \mathrm{Cl1} / \mathrm{Cl} 2(\mathbf{C} 4), \mathrm{OTf}(\mathbf{C} 5) .{ }^{[\mathrm{b}]} \tau_{4}=\frac{360^{\circ}-(\alpha+\beta)}{141}[65] .{ }^{[\mathrm{cc}]} \varrho=\frac{2 a}{(b+c)}$ with $a=d\left(\mathrm{C}_{\text {gua }}=\mathrm{N}_{\text {gua }}\right)$ and $b=c=d\left(\mathrm{C}_{\text {gua }}-\mathrm{N}_{\text {gua }}\right)$ [66]. ${ }^{\mathrm{d}]}$ The angles between the planes represented by $\mathrm{N}_{\text {gua }}, \mathrm{N}_{\text {amine, }}, \mathrm{N}_{\text {amine }}$ and $\mathrm{C}_{\text {gua }}, \mathrm{C}_{\text {alk }}$, $\mathrm{C}_{\mathrm{alk}}$. Average value of the four twist angles for each guanidine moiety of both ligands in the molecular structure. 
The dimethylethyleneguanidine (DMEG) moieties are bridged through a toluene, resulting in an asymmetric structure. To compare the influence of the adjacency to the aromatic part, the guanidine unit binding via the methylene group and the guanidine unit binding directly to the aromatic group are identified as $\mathrm{N}_{\text {gua,aliph }}$ and $\mathrm{N}_{\text {gua,arom, }}$ respectively.

All Cu-N bond lengths of the complexes C1-C4 are in a range of 1.963(2) to 2.097(3) A with the $\mathrm{Cu}(1)-\mathrm{N}_{\text {gua,arom }}$ bond being generally longer than the $\mathrm{Cu}(1)-\mathrm{N}_{\text {gua,aliph }}$ bond, with the exception of $\mathbf{C 1}$, where it is the opposite. This exception of the iodine complex has been observed earlier for the bis(tetramethylguanidino)toluene ( $\mathrm{TMG}_{2}$ tol) copper complex [56]. The largest bite angle of the metal center and the two $\mathrm{N}$-donor atoms is $97.5(1)^{\circ}$ for complex $\mathbf{C 1}$, and the lowest is $92.6(1)^{\circ}$ for the complex $\mathbf{C 4}$, which has two halides at the metal center, explaining the lower bite angle. The trend of a decreasing bite angle from $\mathbf{C} 1$ to $\mathbf{C} 3$ is in agreement with the decreasing copper halide $\mathrm{Cu}-\mathrm{X}$ bond lengths of smaller halides. To determine the coordination environment of the four-fold coordinated complex C4, the $\tau_{4}$ factor was used [65]. A square-planar coordination environment has a $\tau_{4}$ value of 0 , whereas an ideal tetrahedral coordination environment is represented by a value of 1 . The $\tau_{4}$ value of 0.55 of complex $\mathbf{C} 4$ proposes a distorted tetrahedral geometry.

Complex C5, which consists of two ligands and copper atoms and the weakly coordinating triflate, crystallized in the space group Fdd2 and is the highest symmetry structure of all the complexes presented here. The four $\mathrm{Cu}-\mathrm{N}_{\text {gua }}$ bond lengths are the shortest with a range of 1.887(2) to 1.893(2) $\AA$ due to the small coordination number. The bite angles of the two N-donor atoms and the metal centers are 178.1(1) and $178.9(1)^{\circ}$ indicating a close to linear coordination. The intermetallic interaction in the molecular structure of $\mathbf{C} 5$ is weak, as the $\mathrm{Cu} \cdots \mathrm{Cu}$ distance is only 2.732(1) $\AA$, being shorter than $\mathrm{Cu} \cdots \mathrm{Cu}$ distances of the dinuclear cations of bis(guanidine) copper structures studied previously [62].

The strong N-donor effect of guanidines originates from the delocalized double bond. To compare the strength of the delocalization, the structural parameter $\varrho$ was introduced [66]. The ratio of the $\mathrm{C}_{\text {gua }}-\mathrm{N}$ bond length of the $\mathrm{N}$ atom coordinating to the copper center and the two other $\mathrm{C}_{\text {gua }}-\mathrm{N}$ bond lengths of the guanidine moiety is characterized as the parameter $\varrho$. For all complexes $\mathbf{C} \mathbf{1}-\mathbf{C} 5$, the value of $\varrho$ is higher for the guanidine unit closer to the aromatic unit. These results have also been found previously for the $\mathrm{TMG}_{2}$ tol copper complexes [56]. Between the complexes C1-C5, the strength of delocalization is almost the same, except the $\mathrm{Cu}(\mathrm{II})$ complex $\mathrm{C} 4$ has a higher value because of the higher oxidation state [42].

The twisting angle of the guanidine units can be compared by determining the angles between the plane of the three $\mathrm{N}$ atoms $\mathrm{N}_{\text {gua }}, \mathrm{N}_{\text {amine }}, \mathrm{N}_{\text {amine }}$ and the three carbon atoms $\mathrm{C}_{\text {gua }}, \mathrm{C}_{\mathrm{alk}}, \mathrm{C}_{\text {alk }}$ within the guanidine unit. The guanidine twist of the aliphatic guanidines for all complexes $\mathbf{C 1}-\mathbf{C} 5$ is between 16.6 and $17.8^{\circ}$. The guanidines close to the aromatic units have a smaller twisting angle of 12.6 to $12.8^{\circ}$, with the exception of the $\mathrm{Cu}$ (II) complex $\mathrm{C} 4$, which has an angle of $6.4^{\circ}$. The free rotation of the guanidine units closer to the aromatic unit is smaller, resulting in a smaller twisting angle. The additional chloride in complex $\mathbf{C} 4$ increases the hindering effect and may cause the exceptionally smaller value.

\subsection{Oxygen Activation}

Bis(guanidine) copper(I) model complexes are known to form bis( $\mu$-oxido)copper(III) complexes when reacting with dioxygen $[55,67]$. Scheme 3 shows the proposed structure of the bis( $\mu$-oxido) copper(III) species formed by the $\mathrm{Cu}(\mathrm{I})$ complexes $\mathbf{C 1}, \mathbf{C} 5$, and $\mathbf{C 6}$. 


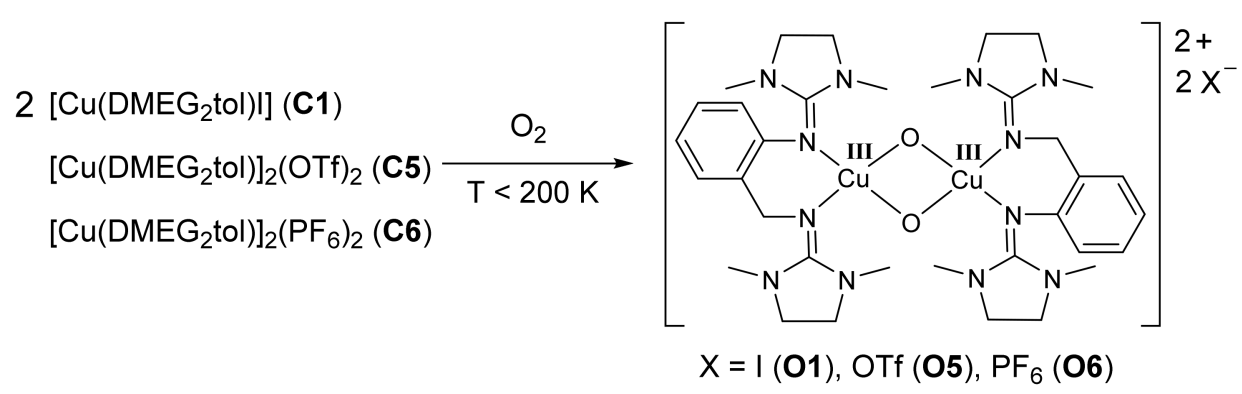

Scheme 3. Activation of dioxygen with the copper(I) complexes C1, C5, and $\mathbf{C 6}$ to form the bis( $\mu$-oxido)copper(III) complexes O1, O5, and $\mathbf{O 6 .}$

The $\mathrm{Cu}(\mathrm{III})$ species of a bis(guanidine) is usually only stable at low temperatures $[56,67]$ with an exception which is stable at ambient temperatures for several days [52]. The $\mathrm{DMEG}_{2}$ tol bis( $\mu$-oxido)copper(III) complexes are only stable long enough to be analyzed by UV/Vis and Raman spectroscopy at temperatures below $200 \mathrm{~K}$. The $\mathrm{Cu}$ (III) species then decays. The formation and decay processes have been analyzed for $\mathrm{Cu}(\mathrm{I})$ complexes of the simple bis(guanidine) ligand btmgp [55]. The UV/Vis spectra of the complexes $\mathbf{O 1}, \mathbf{O 5}$, and $\mathbf{O 6}$ were observed when adding the complexes C1, C5, and $\mathbf{C 6}$ to an $\mathrm{O}_{2}$-saturated solution of dichloromethane (DCM)/acetonitrile (MeCN) $(9: 1, v / v)$ at $195 \mathrm{~K}$. The UV/Vis spectra, measured after the maximum absorption was achieved (after $4 \mathrm{~min}$ ), are represented in Figure 2.

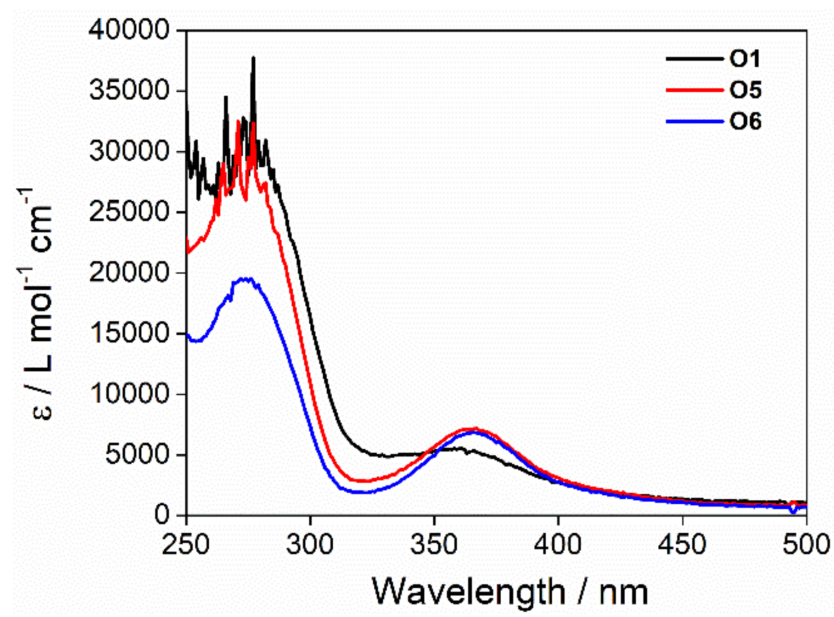

Figure 2. UV/Vis spectra of the bis( $\mu$-oxido)dicopper(III) complexes O1, O5, and O6, measured in $\mathrm{DCM} / \mathrm{MeCN}(9: 1, v / v)$ at $195 \mathrm{~K}$.

The UV/Vis spectrum shows two peaks at 275 and $365 \mathrm{~nm}$ (for O1) or $375 \mathrm{~nm}$ (for O5 and O6). These signals seem to be shifted from the expected characteristic peaks at around 300 and $400 \mathrm{~nm}$, which are assigned to the $\pi_{\sigma^{*}} \rightarrow \mathrm{Cu}_{2} \mathrm{O}_{2}$ and the oxygen $\sigma^{*} \rightarrow \mathrm{Cu}_{2} \mathrm{O}_{2}$ ligand-to-metal charge transfer bands (LMCT), respectively $[9,68]$. Comparing the extinction coefficients found for the $375 \mathrm{~nm}$ band of $\mathrm{O} 5$ and $\mathbf{O} 6$ of $7000 \mathrm{~L} \mathrm{~mol}^{-1} \mathrm{~cm}^{-1}$ to similar complexes of an earlier work with the $\mathrm{TMG}_{2}$ tol ligand of $12,000 \mathrm{~L} \mathrm{~mol}^{-1} \mathrm{~cm}^{-1}$, suggests that the oxido species does not fully form at $195 \mathrm{~K}$ because it already interferes with the decay of the oxido species. The formation of the bis( $\mu$-oxido)dicopper(III) species $\mathbf{O 5}$ and $\mathrm{O} 6$ was followed by UV/Vis spectroscopy. The highly intense band at $275 \mathrm{~nm}$ gains its enormous intensity by $\pi->\pi^{*}$ transitions of the aromatic system.

The UV/Vis spectrum of the bis( $\mu$-oxido)dicopper(III) species reaches its maximum 4 min after initiation. 


\subsection{Raman Spectroscopy}

The oxygenated complex $\mathbf{C} 5$ was analyzed by Raman spectroscopy to confirm the formation of the bis( $\mu$-oxido)dicopper(III) species O5 since the characteristic $400 \mathrm{~nm}$ feature is shifted to $375 \mathrm{~nm}$. The measurements were carried out with the dioxygen isotopes ${ }^{16} \mathrm{O}_{2}$ and ${ }^{18} \mathrm{O}_{2}$ in propionitrile at 188 K, see Figure 3.

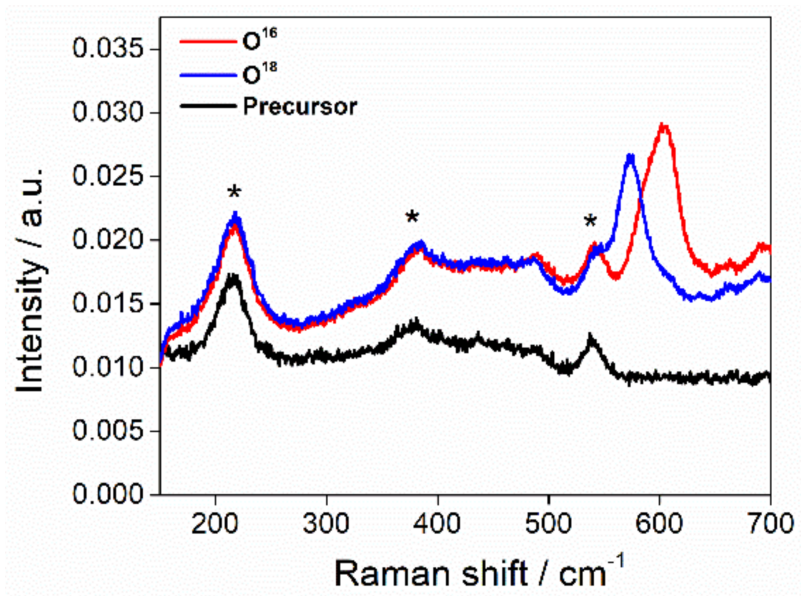

Figure 3. Raman spectrum of the precursor $\mathbf{C 5}$ and the bis( $\mu$-oxido) complex $\mathbf{O 5}$, measured in propionitrile at $188 \mathrm{~K} .{ }^{*}$ represent solvent peaks.

In the Raman spectra a shift of the $\mathrm{Cu}_{2} \mathrm{O}_{2}$ signal from $603 \mathrm{~cm}^{-1}$ to $574 \mathrm{~cm}^{-1}$ was observed upon isotope substitution. This difference of $29 \mathrm{~cm}^{-1}$, originating from oxygen-based vibration, is assigned to the breathing core of $\mathrm{Cu}_{2} \mathrm{O}_{2}$ cores [69]. Raman measurements with dioxygen isotope substitution of the bis(guanidine)copper complexes [Cu(TMG ${ }_{2}$ tol)I] [56] and [Cu(btmgp)I] [70] showed a difference in the $\mathrm{Cu}_{2} \mathrm{O}_{2}$ peaks of $28 \mathrm{~cm}^{-1}$ and $25 \mathrm{~cm}^{-1}$, respectively. The Raman shifts of the dioxygen isotopes ${ }^{16} \mathrm{O}_{2}$ and ${ }^{18} \mathrm{O}_{2}$ are in agreement with the structure of complex $\mathrm{O} 5$ and are in the same range of those of other bis( $\mu$-oxido)dicopper(III) species, reported earlier [29].

\subsection{Density Functional Theory}

For a detailed analysis of the electronic and vibrational characteristics of the desired systems, we performed density functional theory (DFT) $[69,71,72]$ and natural population analysis (NBO) [73-75] calculations.

In previous publications, we recommended the use of the hybrid meta GGA functional TPSSh [76] together with the triple-valence basis set def2-TZVP [77] and empirical dispersion correction with Becke-Johnson damping [78,79] for the calculation of bioinorganic copper complex systems $[55,62,80,81]$.

Table 2 summarizes the characteristic bond lengths of the optimized complexes, the NBO charges, and the charge-transfer energies. The optimized structures are in accordance with the molecular structures in the solid state: The $\mathrm{Cu}-\mathrm{N}_{\text {gua,aliph }}$ bond lengths are longer than the $\mathrm{Cu}-\mathrm{N}_{\text {gua,arom }}$ bond lengths for the complexes $\mathrm{C} 1-\mathrm{C} 3$ whereas in the cation of $\mathrm{C} 5$ these bond lengths are equal. This observation is in accordance with the experimental results. The NBO analysis yields NBO charges and the charge-transfer energies of the complexes. NBO charges do not describe real charges but, rather, the relative electronic situation. In all $\mathrm{Cu}(\mathrm{I})$ complexes, the guanidine $\mathrm{N}$-donors possess a similar charge in the range of -0.67 to $-0.71 \mathrm{e}^{-}$units and also the copper atoms $\left(0.72\right.$ to $\left.0.77 \mathrm{e}^{-}\right)$. In the $\mathrm{Cu}$ (II) complex the $\mathrm{N}_{\text {gua,aliph }}$ donor is slightly more negative than the $\mathrm{N}_{\text {gua,arom }}$ donor and the copper atom possesses a NBO charge of $1.14 \mathrm{e}^{-}$units. The $\mathrm{Cu}-\mathrm{N}_{\text {gua,arom }}$ donor coordinates with shorter bond lengths and this is in accordance with the charge-transfer energies: Shorter bond lengths correspond to larger charge-transfer energies. 
Table 2. Selected bond length $[\AA]$ of the optimized geometry, NBO charges (in $\mathrm{e}^{-}$units) and charge-transfer energies (in $\mathrm{kcal} / \mathrm{mol}$ ) of the complexes $\mathrm{C1}-\mathrm{C} 4$, the cation of $\mathrm{C} 5$ and the $\left[\mathrm{Cu}_{2} \mathrm{O}_{2}\left(\mathrm{DMEG}_{2} \text { tol }\right)_{2}\right]^{2+}$ cation (TPSSh/def2-TZVP, GD3BJ).

\begin{tabular}{|c|c|c|c|c|c|c|}
\hline & C1 & $\mathrm{C} 2$ & $\mathrm{C} 3$ & $\mathrm{C} 4$ & Cation of C5 & {$\left[\mathrm{Cu}_{2} \mathrm{O}_{2}\left(\mathrm{DMEG}_{2} \text { tol }\right)_{2}\right]^{2+}$} \\
\hline \multicolumn{7}{|l|}{ Bond lengths } \\
\hline $\mathrm{Cu}-\mathrm{N}_{\text {gua,aliph }}$ & 2.038 & 2.055 & 2.043 & 1.900 & 1.901 & 1.896 \\
\hline $\mathrm{Cu}-\mathrm{N}_{\text {gua, arom }}$ & 2.008 & 1.996 & 2.010 & 2.011 & 1.909 & 1.916 \\
\hline $\mathrm{Cu}-\mathrm{X}^{[\mathrm{a}]}$ & 2.481 & 2.315 & 2.182 & $2.133 / 2.157$ & & \\
\hline $\begin{array}{c}\mathrm{Cu} \cdots \mathrm{Cu} \\
\mathrm{Cu}-\mathrm{O}\end{array}$ & & & & & 2.595 & $\begin{array}{c}2.734 \\
1.804 / 1.800\end{array}$ \\
\hline \multicolumn{7}{|l|}{ NBO charges } \\
\hline $\mathrm{Cu}$ & 0.72 & 0.75 & 0.77 & 1.14 & 0.77 & 1.36 \\
\hline $\mathrm{N}_{\text {gua,aliph }}$ & -0.71 & -0.69 & -0.67 & -0.61 & -0.71 & -0.64 \\
\hline$\underset{\mathrm{O}}{\mathrm{N}_{\text {gua,arom }}}$ & -0.71 & -0.68 & -0.67 & -0.53 & -0.74 & $\begin{array}{l}-0.71 \\
-0.96\end{array}$ \\
\hline \multicolumn{7}{|l|}{ CT energies } \\
\hline $\mathrm{N}_{\text {gua,aliph }} \rightarrow \mathrm{Cu}$ & 15.2 & 19.4 & 23.2 & cov. ${ }^{[b]}$ & 48.7 & cov. ${ }^{[b]}$ \\
\hline $\mathrm{N}_{\text {gua,arom }} \rightarrow \mathrm{Cu}$ & 28.5 & 32.3 & 31.3 & cov. ${ }^{[b]}$ & 49.7 & cov. ${ }^{[b]}$ \\
\hline
\end{tabular}

In the Raman experiment we obtain the breathing mode at $603 \mathrm{~cm}^{-1}$ and, after isotope exchange, at $574 \mathrm{~cm}^{-1}$. DFT predicts the breathing mode to be at $629 \mathrm{~cm}^{-1}$, shifting to $604 \mathrm{~cm}^{-1}$ upon isotope exchange. The isotope shift hence amounts to $25 \mathrm{~cm}^{-1}$ which is in good agreement with the experimental value of $29 \mathrm{~cm}^{-1}$.

Figure 4 depicts the optimized structure of the bis( $\mu$-oxido) species and the characteristic bond lengths of the core. In comparison to the analogous $\left[\mathrm{Cu}_{2} \mathrm{O}_{2}\left(\mathrm{TMG}_{2} \mathrm{tol}\right)_{2}\right]^{2+}$ oxo complex cation, the $\mathrm{Cu}-\mathrm{N}$ bond lengths are significantly shortened $\left(\mathrm{Cu}-\mathrm{N}\right.$ bond lengths in $\left[\mathrm{Cu}_{2} \mathrm{O}_{2}\left(\mathrm{TMG}_{2} \text { tol }\right)_{2}\right]^{2+}$ cation: 1.902 and $1.938 \AA$ ) and the $\mathrm{Cu} \cdots \mathrm{Cu}$ distance is slightly shortened $\left(\mathrm{Cu} \cdots \mathrm{Cu}\right.$ in $\left[\mathrm{Cu}_{2} \mathrm{O}_{2}\left(\mathrm{TMG}_{2} \text { tol }\right)_{2}\right]^{2+}$ cation: $2.746 \AA$ ) [56]. The $\mathrm{NBO}$ analysis shows that the $\mathrm{N}_{\text {gua,arom }}$ donor (-0.71 $\mathrm{e}^{-}$units) is slightly more basic than the $\mathrm{N}_{\text {gua,aliph }}$ donor (-0.64 $\mathrm{e}^{-}$units). This trend has already been observed in the $\mathrm{Cu}_{2} \mathrm{O}_{2}$ species with the $\mathrm{TMG}_{2}$ tol ligand [56]. The $\mathrm{NBO}$ charge of the copper ions is $1.36 \mathrm{e}^{-}$units and is in accordance with the literature [82].

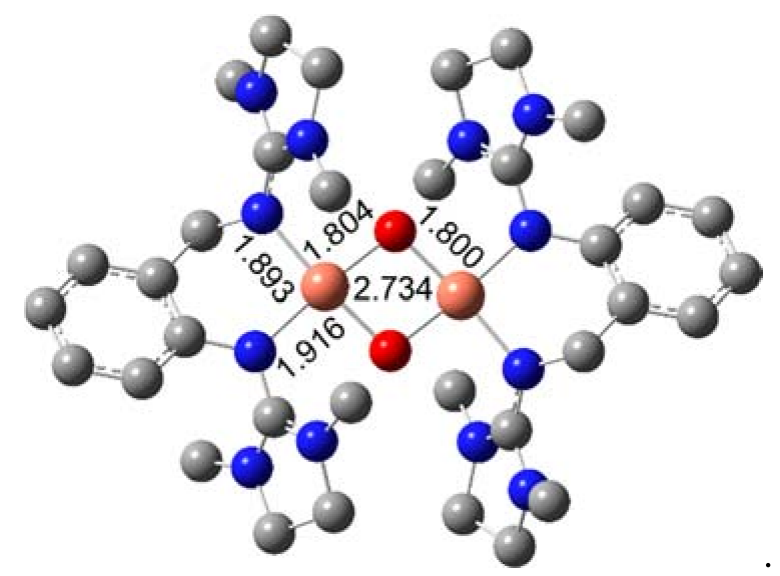

Figure 4. Optimized geometry of the $\left[\mathrm{Cu}_{2} \mathrm{O}_{2}\left(\mathrm{DMEG}_{2} \mathrm{tol}\right)_{2}\right]^{2+}$ cation (TPSSh/def2-TZVP, GD3BJ, hydrogen atoms are omitted for clarity). 


\subsection{Catalysis}

The presented copper complexes are model complexes for the enzyme tyrosinase, which is an effective oxygenation biocatalyst [3,4]. To test whether the complexes are active for substrate oxygenation, complex $\mathbf{O} 1$ was tested in the hydroxylation of 8-hydroxyquinoline, see Scheme 4.

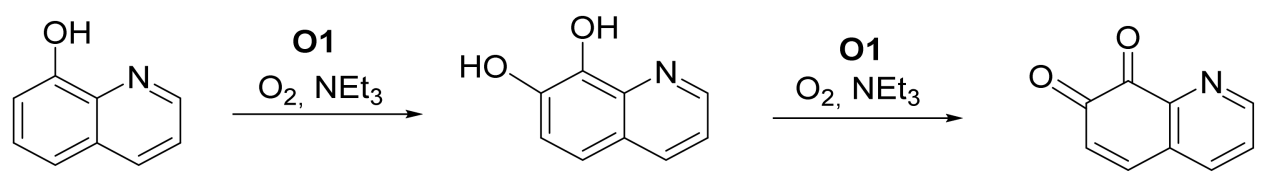

Scheme 4. Hydroxylation of 8-hydroxyquinoline to 7,8-quinolinediol and the subsequent oxidation to 7,8-quinolinedione.

The reaction was carried out following a standard protocol [22,23]. First, the precursor O1 was prepared by adding complex $\mathbf{C} \mathbf{1}$ to a dioxygen saturated solution of tetrahydrofuran (THF) at $195 \mathrm{~K}$. After the formation of the bis( $\mu$-oxido)dicopper(III) species was confirmed via in-situ UV/Vis spectroscopy, 25 equivalents of 8-hydroxyquinoline and 50 equivalents of triethylamine were added.

After the addition of the precursor, the characteristic peak of 7,8-quinolinedione at $413 \mathrm{~nm}$ was observed, as shown in Figure 5. Taking the arguments of the unexpectedly lower extinction coefficient, shown in Section 2.1, into account, we can assume that the bis( $\mu$-oxido) complex has already partly decayed and is only present at $58 \%$, when the maximum extinction was measured. The concentration of the formed product was calculated with the known extinction coefficient of $1000 \mathrm{~L} \mathrm{~mol}^{-1} \mathrm{~cm}^{-1}$ at $413 \mathrm{~nm}$ for 7,8-quinolinedione [83]. This results in a turnover number of 23 for the conversion of 8-hydroxyquinoline. The timeframe between the last measurement of the formation of $\mathbf{O} 1$ and the first measurement after the addition of the substrate is $5.5 \mathrm{~s}$. The process of hydroxylation and subsequent oxidation was extremely fast, as it occurred in less than $5.5 \mathrm{~s}$, even at a temperature of $195 \mathrm{~K}$.

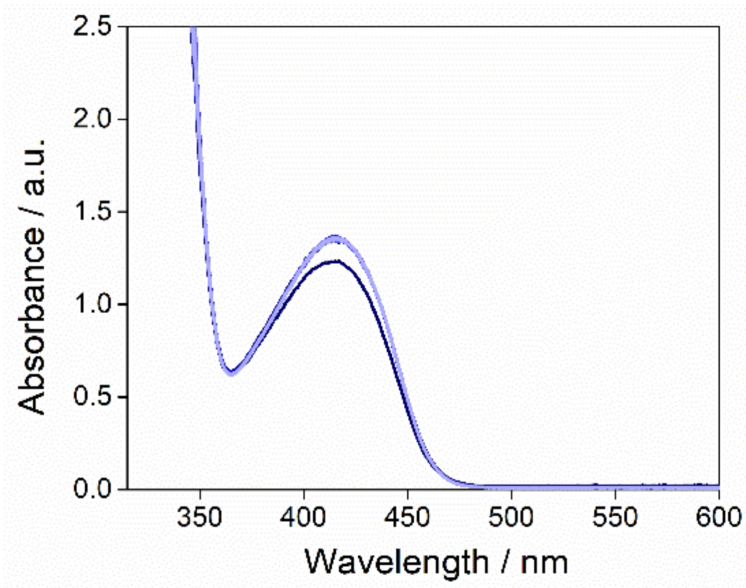

Figure 5. Formation of the 7,8-quinolinedione at $195 \mathrm{~K}$ in tetrahydrofuran (THF).

\subsection{Fluorescence Measurements}

The complex $\mathbf{C} 1$ and two other bis(guanidine) ligands were investigated by fluorescence spectroscopy, see Figure 6. The complexes [Cu(btmgp)I] [62,64] and $\left[\mathrm{Cu}\left(\mathrm{TMG}_{2} \mathrm{tol}\right) \mathrm{I}\right][56]$ have been synthesized and characterized in earlier studies, but, in this study, the fluorescence has been measured with newly prepared complexes for a better comparison. 


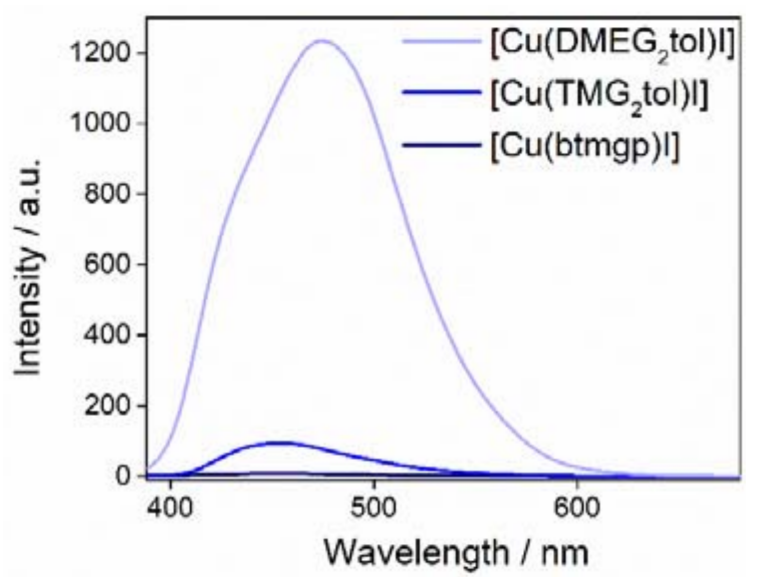

Figure 6. Fluorescence spectra of the complexes [Cu(DMEG ${ }_{2}$ tol $\left.) I\right],\left[\mathrm{Cu}\left(\mathrm{TMG}_{2}\right.\right.$ tol $\left.) \mathrm{I}\right]$, and $[\mathrm{Cu}(\mathrm{btmgp}) \mathrm{I}]$, measured at $298 \mathrm{~K}$ in acetonitrile, with an excitation wavelength of $370 \mathrm{~nm}$.

All measurements have been carried out at $298 \mathrm{~K}$ in acetonitrile at an excitation wavelength of $370 \mathrm{~nm}$. The samples have been prepared in an inert atmosphere with closed cuvettes. The maximum fluorescence intensity of $\left[\mathrm{Cu}\left(\mathrm{TMG}_{2} \mathrm{tol}\right) \mathrm{I}\right]$ at $455 \mathrm{~nm}$ is more than tenfold of the one found at $450 \mathrm{~nm}$ for $[\mathrm{Cu}(\mathrm{btmgp}) \mathrm{I}]$. This effect is caused by the delocalized $\pi$-electrons system of the aromatic unit. This effect is enhanced in complex C1, with DMEG units, compared to the open methyl groups of the TMG units. The measured fluorescence intensity of complex $\mathbf{C} 1$ at $475 \mathrm{~nm}$ is ten times the measured fluorescence intensity of $\left[\mathrm{Cu}\left(\mathrm{TMG}_{2} \mathrm{tol}\right) \mathrm{I}\right]$.

\section{Discussion}

Ligand and complex synthesis are completed straightforward but the hydroxylation activity was completely unexpected since phenolate hydroxylation tests with the related $\mathrm{TMG}_{2}$ tol system completely failed [56]. A further remarkable feature of the reported $\mathrm{DMEG}_{2}$ tol stabilized bis( $\mu$-oxido) dicopper(III) complexes is the shifted UV feature at $375 \mathrm{~nm}$. Normally, this should appear at $400 \mathrm{~nm}$ whereas the LMCT of the isomeric side-on peroxido dicopper(II) species can be found at $350 \mathrm{~nm}$ [14]. However, the Raman measurements support the identification of these species as bis( $\mu$-oxido) species through the characteristic $\mathrm{Cu}_{2} \mathrm{O}_{2}$ breathing mode cores [69]. Since, already, at $-80{ }^{\circ} \mathrm{C}$, the decay of the species competes with its formation, no detailed kinetics can be reported. The related $\mathrm{TMG}_{2}$ tol bis( $\mu$-oxido) species is stable at $-80{ }^{\circ} \mathrm{C}$ for a longer period [56]. The most notable feature is the hydroxylation activity for the special substrate 8-hydroxyquinoline. Up to now, only some bis(pyrazolyl)methane stabilized peroxido species are able to hydroxylate this challenging substrate to its corresponding quinone $[19,37,38]$. It must be noted that the hydroxylation velocity seems to be enormous since the reaction is accomplished in a few seconds at $-80^{\circ} \mathrm{C}$. Further kinetic analysis was prevented by the limited stability of the $\mathrm{Cu}_{2} \mathrm{O}_{2}$ species.

With regard to the desired fluorescence properties, the substitution of TMG against DMEG in the ligand yields a tenfold increase of the fluorescence intensity of the corresponding copper iodide complex, which is useful information for ligand design in general. Moreover, it makes the presented copper(I) complexes valuable for the upcoming studies. Currently, the utilization of the DMEG 2 tol system for laser-induced fluorescence measurements for the detection of mass transfer reactions is under investigation.

\section{Materials and Methods}

All reagents were obtained by TCI GmbH (Eschborn, Germany), Sigma-Aldrich GmbH (Taufkirchen, Germany), ABCR GmbH (Karlsruhe, Germany), Fisher Chemicals (Fisher Scientific, Schwerte, Germany), and Merck KgaA (Darmstadt, Germany) and used as purchased. Acetonitrile, dichloromethane, and propionitrile were heated under reflux over $\mathrm{CaH}_{2}$ and tetrahydrofuran and 
diethyl ether were heated under reflux over sodium. The solvents were then distilled under nitrogen for purification. The solvent was transferred into an inert-gas glovebox for solution preparation. $N, N^{\prime}$-dimethylethylenechloroformamidinium chloride (DMEG-VS) was synthesized as described in the literature [53].

\subsection{General Analytic Methods}

\subsubsection{NMR Spectroscopy}

NMR spectra were recorded with a Jeol EX-400, a Bruker (Karlsruhe, Germany) Avance II (400 MHz) or Bruker Avance III (400 MHz) nuclear resonance spectrometer. Measurements were performed in $\mathrm{CDCl}_{3}$ and the signals were calibrated to the residual signals of the deuterated solvent $\left(\delta_{\mathrm{H}}\left(\mathrm{CHCl}_{3}\right)=7.26 \mathrm{ppm}\right)$.

\subsubsection{IR-Spectroscopy}

IR spectra as KBr pellets were measured with a Thermo Scientific (Waltham, MS, USA) Nicolet Avatar 380 spectrometer. IR spectra were measured in the range $400-4000 \mathrm{~cm}^{-1}$ at a spectral resolution of $1 \mathrm{~cm}^{-1}$.

\subsubsection{Mass-Spectrometry}

ESI mass spectra were obtained with a ThermoFisher Scientific (Waltham, MA, USA) LTQ Orbitrap $\mathrm{XL}$. The source voltage was $4.49 \mathrm{kV}$, and the capillary temperature was $299.54^{\circ} \mathrm{C}$. The tube lens voltage lay between 110 and $130 \mathrm{~V}$.

\subsubsection{UV/Vis Spectroscopy}

UV/Vis spectroscopy measurements were performed on an Agilent Technologies (Santa Clara, CA, USA) Cary $60 \mathrm{UV} /$ Vis spectrophotometer. The spectra were obtained with a quartz glass immersion probe (Helma, $1 \mathrm{~mm}$ ) connected via a Cary 50 fibre optic coupler. The reaction took place in a commercial Schlenk measurement cell.

\subsubsection{Fluorescence Spectroscopy}

The fluorescent emission spectra were recorded on a FL-2500 Fluorescence Spectrophotometer, Hitachi High-Technology Co., Ltd. (Tokyo, Japan). A $3 \mathrm{~mL}$ quartz cuvette was used as sample cell. The fluorescence intensity was measured with an excitation at $370 \mathrm{~nm}$, an emission range from 220 to $800 \mathrm{~nm}$ and a resolution of $1 \mathrm{~nm}$. The spectrophotometer slits for excitation and emission were set at $10 \mathrm{~nm}$.

\subsubsection{Elemental Analysis}

The elemental analyses were performed with an an Elementar varioEL (Langenselbold, Germany).

\subsubsection{X-ray Diffraction Analysis}

The single crystal diffraction data for $\mathbf{C 1}-\mathbf{C 5}$ are presented in Table 3. The data for C1-C5 were collected on a Bruker D8 goniometer with APEX CCD detector (Bruker, Karlsruhe, Germany). An Incoatec microsource with Mo-K $\alpha$ radiation $(\lambda=0.71073 \AA)$ was used and temperature control was achieved with an Oxford Cryostream 700 (Oxford, UK). Crystals were mounted with grease on glass fibers and data were collected at $100 \mathrm{~K}$ in $\omega$-scan mode. Data were collected with SMART [84], integrated with SAINT and corrected for absorption by multi-scan methods with SADABS [85]. The structure was solved by direct and conventional Fourier methods and all non-hydrogen atoms were refined anisotropically with full-matrix least-squares based on $\mathrm{F}^{2}$ (XPREP [86], SHELXS [87] and ShelXle [88]). Hydrogen atoms were derived from difference Fourier maps and placed at idealized 
positions, riding on their parent $C$ atoms, with isotropic displacement parameters $U_{\text {iso }}(H)=1.2 U_{\text {eq }}(C)$ and $1.5 U_{\text {eq }}\left(C_{\text {methyl }}\right)$. All methyl groups were allowed to rotate but not to tip.

In C5 it was not possible to model the disordered solvent molecules $(1 / 2$ molecule THF) in an adequate manner, and the dataset was treated with the SQUEEZE routine as implemented in PLATON $[89,90]$.

Full crystallographic data (excluding structure factors) have been deposited with the Cambridge Crystallographic Data Centre as supplementary no. CCDC-1858298 for C1, CCDC-1858299 for C2, CCDC-1858300 for C3, CCDC-1858301 for C4, and CCDC-1858302 for C5. Copies of the data can be obtained free of charge on application to CCDC, 12 Union Road, Cambridge CB2 1EZ, UK (fax: (+44)1223-336-033; e-mail: deposit@ccdc.cam.ac.uk).

Table 3. Crystallographic data and parameters of complexes C1-C5.

\begin{tabular}{|c|c|c|c|c|c|}
\hline & $\mathrm{C} 1$ & $\mathrm{C} 2$ & C3 & $\mathrm{C} 4$ & C5 \\
\hline Empirical formula & $\mathrm{C}_{17} \mathrm{H}_{26} \mathrm{ICuN}_{6}$ & $\mathrm{C}_{17} \mathrm{H}_{26} \mathrm{BrCuN}_{6}$ & $\mathrm{C}_{17} \mathrm{H}_{26} \mathrm{ClCuN}_{6}$ & $\mathrm{C}_{17} \mathrm{H}_{26} \mathrm{Cl}_{2} \mathrm{CuN}_{6}$ & $\mathrm{C}_{36} \mathrm{H}_{52} \mathrm{Cu}_{2} \mathrm{~F}_{6} \mathrm{~N}_{12} \mathrm{O}_{6} \mathrm{~S}_{2}$ \\
\hline Formula mass $\left[\mathrm{g} \mathrm{mol}^{-1}\right]$ & 504.88 & 457.89 & 413.43 & 448.88 & 1054.10 \\
\hline Crystal size [mm] & $0.23 \times 0.22 \times 0.19$ & $0.40 \times 0.32 \times 0.30$ & $0.38 \times 0.28 \times 0.14$ & $0.28 \times 0.24 \times 0.19$ & $0.34 \times 0.25 \times 0.24$ \\
\hline$T[\mathrm{~K}]$ & $100(2)$ & $100(2)$ & $100(2)$ & $100(2)$ & $100(2)$ \\
\hline Crystal system & orthorhombic & monoclinic & monoclinic & monoclinic & triclinic \\
\hline Space group & $F d d 2$ & $P 2_{1} / c$ & $P 2_{1} / c$ & $P 2_{1} / n$ & $P \overline{1}$ \\
\hline$a[\AA]$ & $18.055(3)$ & $7.194(1)$ & $7.145(1)$ & $15.234(3)$ & $13.869(2)$ \\
\hline$b[\AA]]$ & $26.458(5)$ & $12.813(2)$ & $12.787(2)$ & $8.101(2)$ & $14.096(2)$ \\
\hline$c[\AA]$ & $16.438(3)$ & $20.599(3)$ & $20.530(3)$ & $17.631(3)$ & $14.692(2)$ \\
\hline$\alpha\left[^{\circ}\right]$ & 90 & 90 & 90 & 90 & $112.944(2)$ \\
\hline$\beta\left[^{\circ}\right]$ & 90 & $93.439(2)$ & $93.699(3)$ & $113.072(3)$ & $96.288(2)$ \\
\hline$\gamma\left[{ }^{\circ}\right]$ & 90 & 90 & 90 & 90 & $112.879(2)$ \\
\hline$V\left[\AA^{3}\right]$ & $7852(2)$ & $1895.2(4)$ & $1871.8(5)$ & $2001.8(6)$ & $2319.2(5)$ \\
\hline Z & 16 & 4 & 4 & 4 & 2 \\
\hline$\varrho_{\text {calcd. }}\left[\mathrm{gcm}^{-3}\right]$ & 1.708 & 1.605 & 1.467 & 1.489 & 1.509 \\
\hline$\mu\left[\mathrm{mm}^{-1}\right]$ & 2.698 & 3.273 & 1.322 & 1.372 & 1.087 \\
\hline$\lambda[\AA]$ & 0.71073 & 0.71073 & 0.71073 & 0.71073 & 0.71073 \\
\hline$F(000)$ & 4032 & 936 & 864 & 932 & 1088 \\
\hline$h k l$ range & $\pm 23, \pm 34, \pm 21$ & $\pm 9, \pm 16, \pm 27$ & $\pm 8, \pm 15,-25 \leq l \leq 24$ & $\pm 20, \pm 10, \pm 23$ & $\pm 18, \pm 19, \pm 19$ \\
\hline Reflections collected & 18374 & 25339 & 21427 & 20515 & 33606 \\
\hline Independent reflections & 4665 & 4516 & 3560 & 5052 & 12115 \\
\hline$R_{\text {int. }}$ & 0.0653 & 0.0735 & 0.1084 & 0.0838 & 0.0611 \\
\hline Number of parameters & 230 & 230 & 230 & 239 & 585 \\
\hline$R_{1}[I \geq 2 \sigma(I)]$ & 0.0434 & 0.0360 & 0.0414 & 0.0471 & 0.0446 \\
\hline$\omega \mathrm{R}_{2}$ (all data) & 0.1043 & 0.0900 & 0.1059 & 0.1199 & 0.1092 \\
\hline Goodness-of-fit & 1.095 & 1.045 & 1.035 & 1.031 & 1.010 \\
\hline Largest diff. peak, hole [e $\AA^{-3}$ ] & $-1.304,1.021$ & $-0.912,0.494$ & $-0.524,0.475$ & $-0.555,0.934$ & $-0.455,0.593$ \\
\hline
\end{tabular}

\subsubsection{Raman Spectroscopy}

A Tsunami Ti:Sapphire laser system, model 3950-X1BB (Spectra Physics Lasers Inc., CA, USA) was used for the Raman measurements. The fundamental laser line was frequency doubled to $360 \mathrm{~nm}$ with an FHG, model GWU2 23-PS (GWU-Lasertechnik Vertriebsges. mbH, Erfstadt, Germany). The laser beam was widened with a spatial filter and then focused on the cuvette inside the cryostat. The focus spot size is around $20 \mu \mathrm{m}$. The scattered light was then collected with the UT-3 Raman spectrometer [91]. All spectra were normalized to $1 \mathrm{~s}$ integration time and $1 \mathrm{~mW}$ laser power. The background was subtracted, and the resulting spectra were corrected with the spectrometer sensitivity for the respective wavelength regions. The experiments were conducted in a clean room with constant temperature $\left(20.0 \pm 0.5^{\circ} \mathrm{C}\right)$ and humidity $(45 \% \pm 3 \%)$. For the measurements, a custom-made half-height Suprasil glass cuvette (Hellma Analytics, Müllheim, Germany) with $1.7 \mathrm{~mL}$ sample volume was used. The complex was prepared in an oxygen- and water-free atmosphere $(<0.5 \mathrm{ppm})$ inside a LABstar glovebox (MBraun, Garching, Germany) with a concentration of $5 \mathrm{mM}$ in 99\% propionitrile (Sigma-Aldrich Chemie $\mathrm{GmbH}$, Taufkirchen, Germany). The solvent was degassed by repetitive "freeze-pump-thaw" cycles and dried over a $3 \AA$ molecular sieve. A newly designed cryostat for Raman measurements at the UT-3, which uses a Proline RP890 chiller ethanol chiller (Lauda, Lauda-Königshofen, Germany) with a Peltier module (TEC4-97-49-17-7-05, Thermonamic, China), was used to cool the sample inside the cuvette to a temperature of around $-85{ }^{\circ} \mathrm{C}$ before oxygenation was performed [70]. ${ }^{18} \mathrm{O}_{2}$ (Campro Scientific, Berlin, Germany) was used for oxygenation. 


\subsubsection{Computational Details}

Density functional theory (DFT) calculations were performed with the program suite Gaussian 16, revision A03 [92]. The geometries of the C1-C4, the cation of C5, and the oxido species, see Figure 4, were optimized using the nonlocal hybrid meta GGA TPSSh functional [76] and the triple-zeta basis set def2-TZVP [77] as implemented in Gaussian on all atoms. Furthermore, empirical dispersion correction was used with Becke-Johnson damping factors (GD3BJ) $[78,79,93]$. Frequency calculations did not show imaginary values. NBO calculations for the complexes were accomplished by using the program suite NBO 6.0 [73-75].

\subsection{Synthesis and Characterization}

\subsubsection{Synthesis of the Oxido Complexes O1, O5, and $\mathbf{O 6}$}

The synthesized copper(I) complex was dissolved in $5 \mathrm{~mL}$ distilled acetonitrile (C1 $(0.20 \mathrm{mmol}$, $0.101 \mathrm{~g}), \mathbf{C} 5(0.20 \mathrm{mmol}, 0.122 \mathrm{~g})$, or $\mathbf{C} 6(0.20 \mathrm{mmol}, 0.121 \mathrm{~g})$ in the glovebox and transferred into a $500 \mu \mathrm{m}$ gas-tight Hamilton syringe. A total of $9.5 \mathrm{~mL}$ DCM was added to a Schlenk measurement cell and cooled to $195 \mathrm{~K}$. The solvent was saturated with dioxygen by bubbling dry dioxygen gas $\left(\mathrm{O}_{2} 99.994 \%\right)$ for approximately $10 \mathrm{~min}$ through the solvent against ambient pressure. The copper(I) precursor solution $\left(40.0 \times 10^{-3} \mathrm{~mol} / \mathrm{L}\right)$ was then injected into the oxygenated solution, resulting in a DCM/MeCN ( $v / v$ 9:1) solution with an oxido complex concentration of $1.0 \times 10^{-3} \mathrm{~mol} / \mathrm{L}$. The formation of the oxido species was followed by UV/Vis spectroscopy.

\subsubsection{Catalytic Conversion of 8-Hydroxyquinoline with the Oxido Species}

The oxido complex $\mathbf{O 1}$ was synthesized as described above. Then, a solution of 25 equivalents of 8-hydroxyquinoline and 50 equivalents of triethylamine per oxido complex in $0.2 \mathrm{~mL}$ DCM was added to the solution containing the complex $\mathrm{O} 1$ at $-78{ }^{\circ} \mathrm{C}$. The whole reaction was monitored by in-situ UV/Vis spectroscopy.

Synthesis of 2,2'-(((Dimethylamino)methylene)amino)benzyl)-1,1,3,3-dimethylethyleneguanidine $\left(\mathrm{DMEG}_{2}\right.$ tol) $(\mathbf{L 1})$<smiles>CN1CCN(C)C1=NCc1ccccc1N=C1N(C)CCN1C</smiles>

The DMEG Vilsmeier salt (13.52 g, $80.0 \mathrm{mmol})$ was dissolved in acetonitrile (MeCN) $(95 \mathrm{~mL})$. After a mixture of 2-aminobenzylamine $(39.9 \mathrm{mmol}, 4.87 \mathrm{~g})$ and trimethylamine $(8.10 \mathrm{~g}, 80 \mathrm{mmol}$, $11 \mathrm{~mL}$ ) was dissolved in $\mathrm{MeCN}(50 \mathrm{~mL})$, the solution with the Vilsmeier salt was added dropwise at $0{ }^{\circ} \mathrm{C}$. The reaction mixture was stirred under reflux for $3 \mathrm{~h}$, then a solution of $\mathrm{NaOH}(3.9 \mathrm{~g}, 97 \mathrm{mmol})$ in $15 \mathrm{~mL}$ water was added. The solvent and $\mathrm{NEt}_{3}$ were removed under vacuum. Afterward, $\mathrm{KOH}$ in water $(20 \mathrm{~mL}, 50 \mathrm{wt} \%)$ was added for the complete deprotonation of the guanidine units. The guanidine ligand was extracted with $\mathrm{MeCN}(6 \times 25 \mathrm{~mL})$. The combined organic phase was dried with $\mathrm{Na}_{2} \mathrm{SO}_{4}$ and purified with activated carbon. After the solvent was evaporated under vacuum, the product was obtained as a yellow solid $(11.07 \mathrm{~g}, 35.2 \mathrm{mmol}, 88 \%)$.

${ }^{1} \mathrm{H}$ NMR $\left(400 \mathrm{MHz}, \mathrm{CDCl}_{3}, 25^{\circ} \mathrm{C}\right): \delta=2.50\left(\mathrm{~s}, 6 \mathrm{H}, \mathrm{CH}_{3}\right), 2.74\left(\mathrm{~s}, 6 \mathrm{H}, \mathrm{CH}_{3}\right), 3.10\left(\mathrm{~s}, 4 \mathrm{H}, \mathrm{CH}_{2}\right)$, $3.14\left(\mathrm{~s}, 4 \mathrm{H}, \mathrm{CH}_{2}\right), 4.42\left(\mathrm{~s}, 2 \mathrm{H}, \mathrm{CH}_{2}\right), 6.73\left(\mathrm{dd},{ }^{3} \mathrm{~J}=7.8,{ }^{4} \mathrm{~J}=1.1 \mathrm{~Hz}, 1 \mathrm{H}, \mathrm{CH}_{\text {arom }}\right), 6.82\left(\mathrm{td},{ }^{3} \mathrm{~J}=7.4\right.$, $\left.{ }^{4} J=1.3 \mathrm{~Hz}, 1 \mathrm{H}, \mathrm{CH}_{\text {arom }}\right), 6.96\left(\mathrm{td},{ }^{3} \mathrm{~J}=7.7,{ }^{4} \mathrm{~J}=1.7 \mathrm{~Hz}, 1 \mathrm{H}, \mathrm{CH}_{\text {arom }}\right), 7.41\left(\mathrm{dd},{ }^{3} J=7.6,{ }^{4} J=1.2 \mathrm{~Hz}, 1 \mathrm{H}\right.$, $\left.\mathrm{CH}_{\text {arom }}\right)$ ppm.

${ }^{13} \mathrm{C}\left\{{ }^{1} \mathrm{H}\right\}$ NMR $\left(100 \mathrm{MHz}, \mathrm{CDCl}_{3}, 25^{\circ} \mathrm{C}\right): \delta=35.3\left(\mathrm{CH}_{3}\right), 47.1\left(\mathrm{CH}_{2}\right), 48.8\left(\mathrm{CH}_{2}\right), 120.8\left(\mathrm{C}_{\text {arom }}\right)$, $122.0\left(\mathrm{C}_{\text {arom }}\right), 126.0\left(\mathrm{C}_{\text {arom }}\right), 126.7\left(\mathrm{C}_{\text {arom }}\right), 134.8\left(\mathrm{C}_{\text {arom }}\right), 146.9\left(\mathrm{C}_{\text {arom }}\right), 154.3\left(\mathrm{C}_{\text {gua }}\right), 157.7\left(\mathrm{C}_{\text {gua }}\right) \mathrm{ppm}$. 


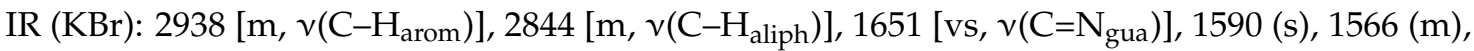
$1480(\mathrm{~m}), 1444(\mathrm{~m}), 1413(\mathrm{~m}), 1390(\mathrm{~m}), 1343(\mathrm{w}), 1278(\mathrm{~m}), 1118(\mathrm{w}), 1067(\mathrm{w}), 1029(\mathrm{w}), 966(\mathrm{w}), 954(\mathrm{w})$, $933(\mathrm{w}), 871(\mathrm{vw}), 777(\mathrm{~m}), 744(\mathrm{~m}), 724(\mathrm{~m}), 710(\mathrm{~m}), 647(\mathrm{w}), 605(\mathrm{w}), 571(\mathrm{w}), 438(\mathrm{w}) \mathrm{cm}^{-1}$.

HRMS (ESI ${ }^{+}$): calcd.: 315.2297, found: 315.2276 (45) [L1 + H: $\left.\mathrm{C}_{17} \mathrm{H}_{27} \mathrm{~N}_{6}\right]^{+}$, calcd.: 202.1344, found: 202.1328 (100) $\left[\mathrm{C}_{12} \mathrm{H}_{16} \mathrm{~N}_{3}\right]^{+}$, calcd.: 187.1110, found: $187.1094(5)\left[\mathrm{C}_{11} \mathrm{H}_{13} \mathrm{~N}_{3}\right]^{+}$, calcd.: 161.0952, found: $161.1065(5)\left[\mathrm{C}_{9} \mathrm{H}_{11} \mathrm{~N}_{3}\right]^{+}$.

Elemental analysis $\left(\mathrm{M}=314.22 \mathrm{~g} \mathrm{~mol}^{-1}\right)$ : calcd. for $\mathrm{C}_{17} \mathrm{H}_{26} \mathrm{~N}_{6}$ : $\mathrm{C} 64.92, \mathrm{H}$ 8.34, N 26.74; found: C 64.32, H 8.43, N 26.42.

$\left[\mathrm{Cu}\left(\mathrm{DMEG}_{2} \mathrm{tol}\right) \mathrm{I}\right](\mathrm{C} \mathbf{1})$

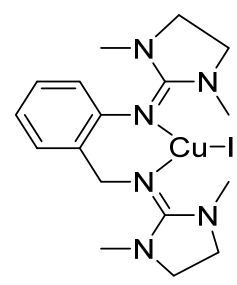

The copper salt CuI $(0.571 \mathrm{~g}, 3.00 \mathrm{mmol})$ was partly dissolved in acetonitrile $(8 \mathrm{~mL})$. A solution of the bis(guanidine) ligand $(0.990 \mathrm{~g}, 3.15 \mathrm{mmol})$, dissolved in acetonitrile $(3 \mathrm{~mL})$, was added. Light yellow crystals were obtained through diffusion of the aprotic solvent diethyl ether $(8 \mathrm{~mL})$ after one day (0.855 g, $1.69 \mathrm{mmol}, 56 \%)$.

${ }^{1} \mathrm{H}$ NMR $\left(400 \mathrm{MHz}, \mathrm{CDCl}_{3}, 25^{\circ} \mathrm{C}\right): \delta=2.86\left(\mathrm{~s}, 6 \mathrm{H}, \mathrm{CH}_{3}\right), 2.99\left(\mathrm{~s}, 6 \mathrm{H}, \mathrm{CH}_{3}\right), 3.34\left(\mathrm{~s}, 4 \mathrm{H}, \mathrm{CH}_{2}\right)$, $3.54\left(\mathrm{~s}, 4 \mathrm{H}, \mathrm{CH}_{2}\right), 4.44\left(\mathrm{~s}, 2 \mathrm{H}, \mathrm{CH}_{2}\right), 6.70\left(\mathrm{dd}, J=8.0,1.2 \mathrm{~Hz}, 1 \mathrm{H}, \mathrm{CH}_{\text {arom }}\right), 6.76(\mathrm{td}, J=7.4,1.3 \mathrm{~Hz}, 1 \mathrm{H}$, $\left.\mathrm{CH}_{\text {arom }}\right), 7.03\left(\mathrm{dd}, J=7.4,1.7 \mathrm{~Hz}, 1 \mathrm{H}, \mathrm{CH}_{\text {arom }}\right), 7.09\left(\mathrm{td}, J=7.6,1.7 \mathrm{~Hz}, 1 \mathrm{H}, \mathrm{CH}_{\text {arom }}\right) \mathrm{ppm}$.

${ }^{13} \mathrm{C}\left\{{ }^{1} \mathrm{H}\right\} \mathrm{NMR}\left(100 \mathrm{MHz}, \mathrm{CDCl}_{3}, 25^{\circ} \mathrm{C}\right): \delta=36.2\left(\mathrm{CH}_{3}\right), 38.2\left(\mathrm{CH}_{3}\right), 48.3\left(\mathrm{CH}_{2}\right), 49.6\left(\mathrm{CH}_{2}\right)$, $119.8\left(\mathrm{C}_{\text {arom }}\right), 121.3\left(\mathrm{C}_{\text {arom }}\right), 128.0\left(\mathrm{C}_{\text {arom }}\right), 129.6\left(\mathrm{C}_{\text {arom }}\right), 132.0\left(\mathrm{C}_{\text {arom }}\right), 148.3\left(\mathrm{C}_{\text {gua }}\right), 162.3$ ( $\left.\mathrm{C}_{\text {gua }}\right)$, $164.4\left(\mathrm{C}_{\text {gua }}\right) \mathrm{ppm}$.

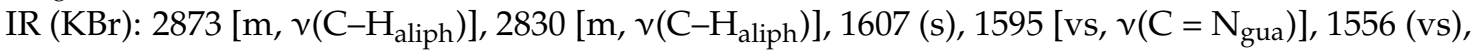
$1475(\mathrm{~m}), 1443(\mathrm{~m}), 1413(\mathrm{~m}), 1387(\mathrm{~m}), 1350(\mathrm{~m}), 1286(\mathrm{~m}), 1261(\mathrm{~m}), 1241(\mathrm{~m}), 1155(\mathrm{w}), 1111(\mathrm{w})$, $1056(\mathrm{~m}), 1043(\mathrm{~m}), 1019(\mathrm{~m}), 960(\mathrm{~m}), 935(\mathrm{~m}), 885(\mathrm{~m}), 809(\mathrm{~m}), 771(\mathrm{~m}), 752(\mathrm{~m}), 720(\mathrm{~m}), 648(\mathrm{~m})$, $615(\mathrm{~m}), 569(\mathrm{~m}), 453(\mathrm{~m}) \mathrm{cm}^{-1}$.

HRMS (ESI ${ }^{+}$): calcd.: 377.1515 , found: $377.1501(10)\left[\mathrm{C}_{17} \mathrm{H}_{26}{ }^{63} \mathrm{CuN}_{6}\right]^{+}$, calcd.: 315.2297 , found: 315.2284 (8) $\left[\mathrm{C}_{17} \mathrm{H}_{27} \mathrm{~N}_{6}\right]^{+}$, calcd.: 202.1344, found: $202.1334(100)\left[\mathrm{C}_{12} \mathrm{H}_{16} \mathrm{~N}_{3}\right]^{+}$, calcd.: 187.1110, found: $187.1100(8)\left[\mathrm{C}_{11} \mathrm{H}_{13} \mathrm{~N}_{3}\right]^{+}$.

Elemental analysis $\left(\mathrm{M}=504.67 \mathrm{~g} \mathrm{~mol}^{-1}\right)$ : calcd. for $\mathrm{C}_{17} \mathrm{H}_{26} \mathrm{~N}_{6} \mathrm{CuI}$ : C 40.42, H 5.19, N 16.65; found: C 40.39, H 4.90, N 16.52.

$\left[\mathrm{Cu}\left(\mathrm{DMEG}_{2}\right.\right.$ tol $\left.) \mathrm{Br}\right](\mathrm{C} 2)$

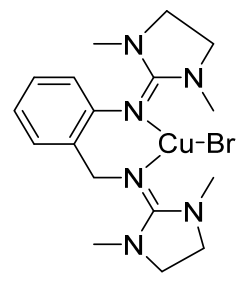

A mixture of $\mathrm{CuBr}(0.035 \mathrm{~g}, 0.24 \mathrm{mmol})$ and the ligand $\mathbf{L 1}(0.101 \mathrm{~g}, 0.32 \mathrm{mmol})$ in tetrahydrofuran $(3 \mathrm{~mL})$ was heated to approximately $70{ }^{\circ} \mathrm{C}$. Colorless needles were obtained after the solution had cooled down $(0.065 \mathrm{~g}, 0.14 \mathrm{mmol}, 58 \%)$.

${ }^{1} \mathrm{H}$ NMR $\left(400 \mathrm{MHz}, \mathrm{CDCl}_{3}, 25^{\circ} \mathrm{C}\right): \delta=2.75\left(\mathrm{~s}, 6 \mathrm{H}, \mathrm{CH}_{3}\right), 3.01\left(\mathrm{~s}, 6 \mathrm{H}, \mathrm{CH}_{3}\right), 3.39\left(\mathrm{~s}, 4 \mathrm{H}, \mathrm{CH}_{2}\right)$, $3.41\left(\mathrm{~s}, 4 \mathrm{H}, \mathrm{CH}_{2}\right), 4.45\left(\mathrm{~s}, 2 \mathrm{H}, \mathrm{CH}_{2}\right), 6.70-6.77\left(\mathrm{~m}, 1 \mathrm{H}, \mathrm{CH}_{\text {arom }}\right), 6.80\left(\mathrm{t}, J=7.4 \mathrm{~Hz}, 1 \mathrm{H}, \mathrm{CH}_{\text {arom }}\right), 7.04-7.13$ (m, $2 \mathrm{H}, \mathrm{CH}_{2}, \mathrm{CH}_{\text {arom }}$ ) ppm. 
${ }^{13} \mathrm{C}\left\{{ }^{1} \mathrm{H}\right\}$ NMR $\left(100 \mathrm{MHz}, \mathrm{CDCl}_{3}, 25{ }^{\circ} \mathrm{C}\right): \delta=35.7\left(\mathrm{CH}_{3}\right), 37.2\left(\mathrm{CH}_{3}\right), 48.6\left(\mathrm{CH}_{2}\right), 49.6\left(\mathrm{CH}_{2}\right)$, 120.7 ( $\left.\mathrm{C}_{\text {arom }}\right), 122.4\left(\mathrm{C}_{\text {arom }}\right), 128.0\left(\mathrm{C}_{\text {arom }}\right), 128.8\left(\mathrm{C}_{\text {arom }}\right), 148.1\left(\mathrm{C}_{\text {gua }}\right) \mathrm{ppm}$. The signal of the second $\mathrm{C}_{\text {gua }}$ is too weak due to the low solubility of the complex.

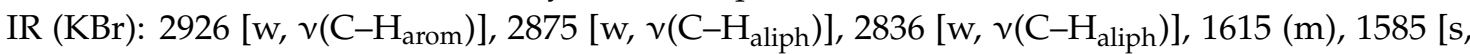
$\left.v\left(\mathrm{C}=\mathrm{N}_{\text {gua }}\right)\right], 1567(\mathrm{~m}), 1515(\mathrm{~m}), 1479(\mathrm{~m}), 1450(\mathrm{~m}), 1384(\mathrm{vs}), 1343(\mathrm{~m}), 1277(\mathrm{~m}), 1202(\mathrm{~m}), 1118(\mathrm{~m})$, $1043(\mathrm{~m}), 961(\mathrm{w}), 748(\mathrm{~m}) \mathrm{cm}^{-1}$.

HRMS (ESI ${ }^{+}$): calcd.: 377.1515, found: $377.1556(75)\left[\mathrm{C}_{17} \mathrm{H}_{26}{ }^{63} \mathrm{CuN}_{6}\right]^{+}$, calcd.: 315.2297, found: 315.2329 (25) $\left[\mathrm{C}_{17} \mathrm{H}_{27} \mathrm{~N}_{6}\right]^{+}$, calcd.: 202.1344, found: 202.1363 (100) $\left[\mathrm{C}_{12} \mathrm{H}_{16} \mathrm{~N}_{3}\right]^{+}$, calcd.: 186.1031, found: 186.1050 (65) $\left[\mathrm{C}_{11} \mathrm{H}_{12} \mathrm{~N}_{3}\right]^{+}$.

Elemental analysis $\left(\mathrm{M}=457.67 \mathrm{~g} \mathrm{~mol}^{-1}\right)$ : calcd. for $\mathrm{C}_{17} \mathrm{H}_{26} \mathrm{~N}_{6} \mathrm{CuBr}$ : C 44.57, $\mathrm{H}$ 5.73, $\mathrm{N}$ 18.36; found: C 44.76, H 5.66, N 18.45.

$\left[\mathrm{Cu}\left(\mathrm{DMEG}_{2}\right.\right.$ tol $\left.) \mathrm{Cl}\right](\mathrm{C} 3)$<smiles></smiles>

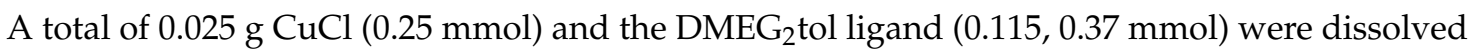
in tetrahydrofuran $(4 \mathrm{~mL})$ and heated to approximately $70{ }^{\circ} \mathrm{C}$. Diethyl ether $(1 \mathrm{~mL})$ was layered on this THF solution so it could slowly diffuse into the solution. Colorless needles were obtained after one week $(0.051 \mathrm{~g}, 0.12 \mathrm{mmol}, 48 \%)$.

${ }^{1} \mathrm{H} \mathrm{NMR}\left(400 \mathrm{MHz} \mathrm{CDCl}_{3}, 25{ }^{\circ} \mathrm{C}\right): \delta=2.72\left(\mathrm{~s}, 6 \mathrm{H}, \mathrm{CH}_{3}\right), 3.02\left(\mathrm{~s}, 6 \mathrm{H}, \mathrm{CH}_{3}\right), 3.37\left(\mathrm{~s}, 4 \mathrm{H}, \mathrm{CH}_{2}\right)$, $3.41\left(\mathrm{~s}, 4 \mathrm{H}, \mathrm{CH}_{2}\right), 4.46\left(\mathrm{~s}, 2 \mathrm{H}, \mathrm{CH}_{2}\right), 6.77\left(\mathrm{~d}, J=7.5 \mathrm{~Hz}, 1 \mathrm{H}, \mathrm{CH}_{\text {arom }}\right), 6.83\left(\mathrm{t}, J=7.1 \mathrm{~Hz}, 1 \mathrm{H}, \mathrm{CH}_{\text {arom }}\right)$, 7.06-7.12 (m, 1H, CH $\left.\mathrm{Ham}_{\text {arom }}\right), 7.14\left(\mathrm{~d}, J=7.5 \mathrm{~Hz}, 1 \mathrm{H}, \mathrm{CH}_{\text {arom }}\right)$ ppm.

Due to the very low solubility of the complex, a ${ }^{13} \mathrm{C}$ NMR spectrum could not be obtained for the complex C3.

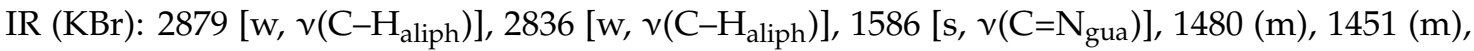
1384 (vs), 1343 (m), 1278 (m), 1116 (m), 1042 (m), 961 (m), 887 (m), 797 (m), $747(\mathrm{~m}), 616\left(\mathrm{~m}^{2} \mathrm{~cm}^{-1}\right.$.

HRMS (ESI ${ }^{+}$): calcd.: 377.1515, found: $377.1545(45)\left[\mathrm{C}_{17} \mathrm{H}_{26}{ }^{63} \mathrm{CuN}_{6}\right]^{+}$, calcd.: 315.2297 , found: 315.2320 (20) $\left[\mathrm{C}_{17} \mathrm{H}_{27} \mathrm{~N}_{6}\right]^{+}$, calcd.: 202.1344, found: 202.1357 (100) $\left[\mathrm{C}_{12} \mathrm{H}_{16} \mathrm{~N}_{3}\right]^{+}$, calcd.: 186.1031, found: 186.1045 (27) $\left[\mathrm{C}_{11} \mathrm{H}_{12} \mathrm{~N}_{3}\right]^{+}$.

Elemental analysis $\left(\mathrm{M}=413.22 \mathrm{~g} \mathrm{~mol}^{-1}\right)$ : calcd. for $\mathrm{C}_{17} \mathrm{H}_{26} \mathrm{~N}_{6} \mathrm{CuCl}: \mathrm{C}$ 49.37, $\mathrm{H}$ 6.34, $\mathrm{N}$ 20.33; found: C 49.32, H 6.18, N 20.45.

$\left[\mathrm{Cu}\left(\mathrm{DMEG}_{2}\right.\right.$ tol $\left.) \mathrm{Cl}_{2}\right](\mathrm{C} 4)$<smiles>CN1CCN(C)C1=NC(=NC1=NCN(C)C1Cl)c1ccccc1Cl</smiles>

Copper dichloride $(0.067 \mathrm{~g}, 0.50 \mathrm{mmol})$ was added to acetonitrile $(0.8 \mathrm{~mL})$. The $\mathrm{DMEG}_{2}$ tol ligand $(0.174 \mathrm{~g}, 0.55 \mathrm{mmol})$ was dissolved in THF $(2.5 \mathrm{~mL})$ and added to the copper dichloride solution. Dark red crystals were obtained through diffusion of the aprotic solvent diethyl ether $(6 \mathrm{~mL})$ after three days $(0.107 \mathrm{~g}, 0.24 \mathrm{mmol}, 48 \%)$. 


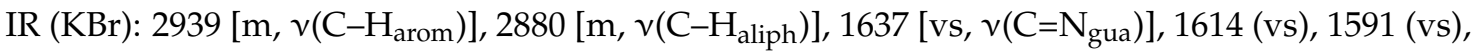
$1541(\mathrm{~s}), 1490(\mathrm{~s}), 1446(\mathrm{~m}), 1411(\mathrm{~m}), 1371(\mathrm{~s}), 1286(\mathrm{~s}), 1237(\mathrm{~m}), 1121(\mathrm{~m}), 1074(\mathrm{~m}), 1032(\mathrm{~m}), 969(\mathrm{~m})$, $936(\mathrm{w}), 888(\mathrm{~m}), 842(\mathrm{w}), 809(\mathrm{~m}), 778(\mathrm{~m}), 760(\mathrm{~m}), 738(\mathrm{~m}), 696(\mathrm{~m}), 620(\mathrm{~m}), 571(\mathrm{~m}), 474(\mathrm{~m}) \mathrm{cm}^{-1}$.

HRMS (ESI ${ }^{+}$): calcd.: 412.1204, found: 412.1187 (1) $\left[\mathrm{C}_{17} \mathrm{H}_{26}{ }^{63} \mathrm{CuN}_{6}{ }^{35} \mathrm{Cl}\right]^{+}$, calcd.: 315.2297 , found: 315.2285 (48) $\left[\mathrm{C}_{17} \mathrm{H}_{27} \mathrm{~N}_{6}=\mathrm{L} 1+1\right]^{+}$, calcd.: 202.1344, found: 202.1335 (100) $\left[\mathrm{C}_{12} \mathrm{H}_{16} \mathrm{~N}_{3}\right]^{+}$, calcd.: 187.1110, found: $187.1100(4)\left[\mathrm{C}_{11} \mathrm{H}_{13} \mathrm{~N}_{3}\right]^{+}$.

Elemental analysis $\left(\mathrm{M}=448.67 \mathrm{~g} \mathrm{~mol}^{-1}\right)$ : calcd. for $\mathrm{C}_{17} \mathrm{H}_{26} \mathrm{~N}_{6} \mathrm{CuCl}_{2}$ : $\mathrm{C} 45.47, \mathrm{H} 5.84, \mathrm{~N} 18.73$; found: C 45.48, H 5.77, N 18.65 .

$\left[\mathrm{Cu}\left(\mathrm{DMEG}_{2} \text { tol }\right)\right]_{2}(\mathrm{OTf})_{2}(\mathrm{C} 5)$

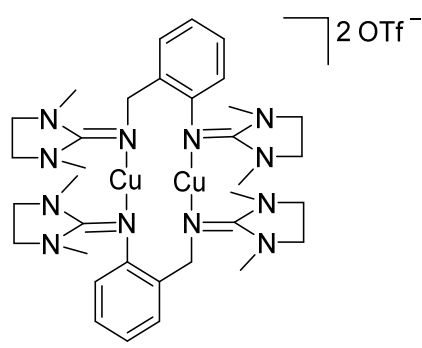

$\left[\mathrm{Cu}(\mathrm{MeCN})_{4}\right]\left(\mathrm{CF}_{3} \mathrm{SO}_{3}\right)(0.094 \mathrm{~g}, 0.25 \mathrm{mmol})$ was dissolved in acetonitrile $(0.25 \mathrm{~mL})$ and the solution was heated to approximately $70{ }^{\circ} \mathrm{C}$. Ligand $\mathbf{L 1}(0.088 \mathrm{~g}, 0.28 \mathrm{mmol})$ was dissolved in acetonitrile $(0.75 \mathrm{~mL})$ and added to the hot copper triflate solution. Afterwards tetrahydrofuran $(3.5 \mathrm{~mL})$ and diethylether $(3.5 \mathrm{~mL})$ were slowly added consecutively to the surface of the solution. After one day, light yellow crystals were obtained $(0.171 \mathrm{~g}, 0.14 \mathrm{mmol}, 56 \%)$.

${ }^{1} \mathrm{H}$ NMR $\left(400 \mathrm{MHz}, \mathrm{CD}_{3} \mathrm{CN}, 25^{\circ} \mathrm{C}\right): \delta=2.62\left(\mathrm{~s}, 6 \mathrm{H}, \mathrm{CH}_{3}\right), 2.88\left(\mathrm{~s}, 6 \mathrm{H}, \mathrm{CH}_{3}\right), 3.36\left(\mathrm{~s}, 4 \mathrm{H}, \mathrm{CH}_{2}\right)$, $3.39\left(\mathrm{~s}, 4 \mathrm{H}, \mathrm{CH}_{2}\right), 4.35\left(\mathrm{~s}, 2 \mathrm{H}, \mathrm{CH}_{2}\right), 6.77\left(\mathrm{dd}, J=7.8,1.3 \mathrm{~Hz}, 1 \mathrm{H}, \mathrm{CH}_{\text {arom }}\right), 6.88(\mathrm{td}, J=7.4,1.3 \mathrm{~Hz}, 1 \mathrm{H}$, $\left.\mathrm{CH}_{\text {arom }}\right), 7.07\left(\mathrm{dd}, J=7.5,1.7 \mathrm{~Hz}, 1 \mathrm{H}, \mathrm{CH}_{\text {arom }}\right), 7.14\left(\mathrm{td}, J=7.6,1.7 \mathrm{~Hz}, 1 \mathrm{H}, \mathrm{CH}_{\text {arom }}\right) \mathrm{ppm}$.

${ }^{13} \mathrm{C}\left\{{ }^{1} \mathrm{H}\right\}$ NMR $\left(100 \mathrm{MHz}, \mathrm{CD}_{3} \mathrm{CN}, 25{ }^{\circ} \mathrm{C}\right): \delta=35.7\left(\mathrm{CH}_{3}\right), 37.3\left(\mathrm{CH}_{3}\right), 49.3\left(\mathrm{CH}_{2}\right), 50.2\left(\mathrm{CH}_{2}\right)$, $122.6\left(\mathrm{C}_{\text {arom }}\right), 124.4\left(\mathrm{C}_{\text {arom }}\right), 129.1\left(\mathrm{C}_{\text {arom }}\right), 130.3\left(\mathrm{C}_{\text {arom }}\right), 134.0\left(\mathrm{C}_{\text {arom }}\right), 149.4$ ( $\left.\mathrm{C}_{\text {gua }}\right), 161.9$ ( $\left.\mathrm{C}_{\text {gua }}\right)$, 165.5 ( $\left.\mathrm{C}_{\text {gua }}\right) \mathrm{ppm}$.

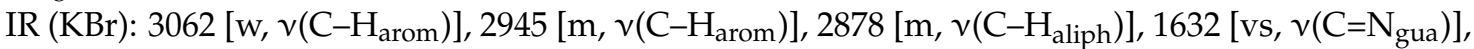
1583 (vs), 1561 (s), 1484 (s), 1448 (s), 1419 (m), 1402 (m), 1348 (m), 1263 (vs), 1224 (s), 1156 (vs), 1067 (w), 1030 (vs), $969(\mathrm{w}), 938(\mathrm{vw}), 883(\mathrm{vw}), 833(\mathrm{vw}), 780(\mathrm{vw}), 753(\mathrm{~m}), 722(\mathrm{vw}), 637(\mathrm{vs}), 571(\mathrm{~m}), 516(\mathrm{~m})$, $471(\mathrm{~m}) \mathrm{cm}^{-1}$.

HRMS (ESI ${ }^{+}$): calcd.: 377.1515 , found: 377.1509 (100) $\left[\mathrm{C}_{17} \mathrm{H}_{26}{ }^{63} \mathrm{CuN}_{6}\right]^{+}$, calcd.: 313.2141 , found: 313.2131 (12) $\left[\mathrm{C}_{17} \mathrm{H}_{25} \mathrm{~N}_{6}\right]^{+}$, calcd.: 202.1344, found: $202.1335(9)\left[\mathrm{C}_{12} \mathrm{H}_{16} \mathrm{~N}_{3}\right]^{+}$.

Elemental analysis $\left(\mathrm{M}=1053.44 \mathrm{~g} \mathrm{~mol}^{-1}\right)$ : calcd. for $\mathrm{C}_{36} \mathrm{H}_{52} \mathrm{~N}_{12} \mathrm{Cu}_{2} \mathrm{~F}_{6} \mathrm{~S}_{2} \mathrm{O}_{6}$ : C 41.01, $\mathrm{H}$ 4.97, N 15.95; found: C 42.45, H 5.38, N 16.09 .

$\left[\mathrm{Cu}\left(\mathrm{DMEG}_{2} \mathrm{tol}\right)\right]_{2}\left(\mathrm{PF}_{6}\right)_{2}(\mathrm{C} 6)$

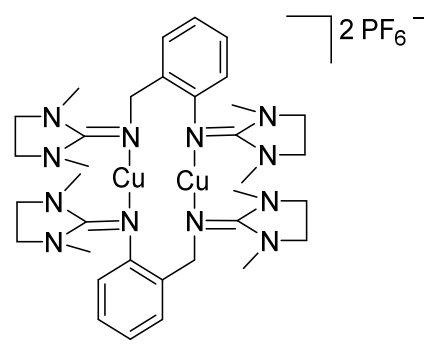

$\left[\mathrm{Cu}(\mathrm{MeCN})_{4}\right]\left(\mathrm{PF}_{6}\right)(0.093 \mathrm{~g}, 0.25 \mathrm{mmol})$ was added to acetonitrile $(4 \mathrm{~mL})$, and the solution was heated to approximately $70{ }^{\circ} \mathrm{C}$. Then, a mixture of the $\mathrm{DMEG}_{2}$ tol ligand $(0.085 \mathrm{~g}, 0.27 \mathrm{mmol})$ in $2 \mathrm{~mL}$ acetonitrile was added to the hot $\left[\mathrm{Cu}(\mathrm{MeCN})_{4}\right]\left(\mathrm{PF}_{6}\right)$ solution. Tetrahydrofuran $(4 \mathrm{~mL})$ and diethyl ether 
( $4 \mathrm{~mL}$ ) were slowly added to the surface of the solution, consecutively. The impurities of the formed brownish crystals were removed through recrystallizing with acetonitrile $(4 \mathrm{~mL})$ and diethyl ether (6 mL). Overnight, the product was obtained in the form of yellow crystals $(0.148 \mathrm{~g}, 0.12 \mathrm{mmol}, 48 \%)$.

${ }^{1} \mathrm{H}$ NMR $\left(400 \mathrm{MHz}, \mathrm{CD}_{3} \mathrm{CN}, 25^{\circ} \mathrm{C}\right): \delta=2.66\left(\mathrm{~s}, 6 \mathrm{H}, \mathrm{CH}_{3}\right), 2.91\left(\mathrm{~s}, 6 \mathrm{H}, \mathrm{CH}_{3}\right), 3.39\left(\mathrm{~s}, 4 \mathrm{H}, \mathrm{CH}_{2}\right)$, $3.43\left(\mathrm{~s}, 4 \mathrm{H}, \mathrm{CH}_{2}\right), 4.38\left(\mathrm{~s}, 2 \mathrm{H}, \mathrm{CH}_{2}\right), 6.81\left(\mathrm{dd}, J=7.9,1.3 \mathrm{~Hz}, 1 \mathrm{H}, \mathrm{CH}_{\text {arom }}\right), 6.91(\mathrm{td}, J=7.4,1.3 \mathrm{~Hz}, 1 \mathrm{H}$, $\left.\mathrm{CH}_{\text {arom }}\right), 7.10\left(\mathrm{dd}, J=7.5,1.7 \mathrm{~Hz}, 1 \mathrm{H}, \mathrm{CH}_{\text {arom }}\right), 7.18\left(\mathrm{td}, J=7.6,1.7 \mathrm{~Hz}, 1 \mathrm{H}, \mathrm{CH}_{\text {arom }}\right)$ ppm.

${ }^{13} \mathrm{C}\left\{{ }^{1} \mathrm{H}\right\}$ NMR $\left(100 \mathrm{MHz}, \mathrm{CD}_{3} \mathrm{CN}, 25{ }^{\circ} \mathrm{C}\right): \delta=35.7\left(\mathrm{CH}_{3}\right), 37.3\left(\mathrm{CH}_{3}\right), 49.3\left(\mathrm{CH}_{2}\right), 50.3\left(\mathrm{CH}_{2}\right)$, $122.7\left(\mathrm{C}_{\text {arom }}\right), 124.4\left(\mathrm{C}_{\text {arom }}\right), 129.2\left(\mathrm{C}_{\text {arom }}\right), 130.4\left(\mathrm{C}_{\text {arom }}\right), 134.0\left(\mathrm{C}_{\text {arom }}\right), 149.4\left(\mathrm{C}_{\text {gua }}\right), 162.3$ ( $\left.\mathrm{C}_{\text {gua }}\right)$, 165.6 ( ( gua $)$ ppm.

IR (KBr): $2980\left[\mathrm{w}, v\left(\mathrm{C}-\mathrm{H}_{\text {arom }}\right)\right], 2940\left[\mathrm{w}, v\left(\mathrm{C}-\mathrm{H}_{\text {arom }}\right)\right], 2867\left[\mathrm{w}, v\left(\mathrm{C}-\mathrm{H}_{\text {aliph }}\right)\right], 1638$ (s), 1617 [s, v(C=N gua $)$ ], $1565(\mathrm{~m}), 1506(\mathrm{~m}), 1485(\mathrm{~m}), 1447(\mathrm{w}), 1418(\mathrm{~m}), 1402(\mathrm{~m}), 1384(\mathrm{w}), 1348(\mathrm{vw})$, $1292(\mathrm{~m}), 1232(\mathrm{w}), 1115(\mathrm{vw}), 1034(\mathrm{w}), 972(\mathrm{vw}), 837(\mathrm{vs}), 753(\mathrm{w}), 719(\mathrm{vw}), 696(\mathrm{vw}), 640(\mathrm{w}), 614(\mathrm{w})$, $557(\mathrm{~s}), 525(\mathrm{vw}), 482(\mathrm{w}), 420(\mathrm{w}) \mathrm{cm}^{-1}$.

HRMS (ESI ${ }^{+}$): calcd.: 377.1515 , found: $377.1502(25)\left[\mathrm{C}_{17} \mathrm{H}_{26}{ }^{63} \mathrm{CuN}_{6}\right]^{+}$, calcd.: 315.2297 , found: 315.2285 (9) $\left[\mathrm{C}_{17} \mathrm{H}_{27} \mathrm{~N}_{6}\right]^{+}$, calcd.: 202.1344, found: 202.1335 (100) $\left[\mathrm{C}_{12} \mathrm{H}_{16} \mathrm{~N}_{3}\right]^{+}$, calcd.: 187.1110, found: 187.1098 (17) $\left[\mathrm{C}_{11} \mathrm{H}_{13} \mathrm{~N}_{3}\right]^{+}$, calcd.: 161.0952, found: $161.1070(1)\left[\mathrm{C}_{9} \mathrm{H}_{11} \mathrm{~N}_{3}\right]^{+}$.

Elemental analysis $\left(\mathrm{M}=1045.46 \mathrm{~g} \mathrm{~mol}^{-1}\right)$ : calcd. for $\mathrm{C}_{34} \mathrm{H}_{52} \mathrm{~N}_{12} \mathrm{Cu}_{2} \mathrm{P}_{2} \mathrm{~F}_{12}$ : C 39.00, H 5.01, N 16.07; found: C 38.51, H 4.48, N 15.72.

\section{Conclusions}

Herein, we presented the synthesis of a new bis(guanidine) and its copper complexes. The $\mathrm{Cu}(\mathrm{I})$ complexes possess a stronger fluorescence than their preceding bis(guanidine) relatives. Moreover, the copper(I) complexes are able to activate dioxygen, and at a low temperature bis( $\mu$-oxido) dicopper(III) species are formed. These are able to catalytically hydroxylate 8-hydroxyquinoline to the corresponding quinone which is remarkable for bis(guanidine) complexes.

Supplementary Materials: The following materials are available online at http:/ /www.mdpi.com/2304-6740/6/ 4/114/s1, Figure S1-S9: NMR Spectra of the Complexes C1-C3, C5-C6. CIF and check CIF files of C1-C5.

Author Contributions: The study was conceptualized by S.H.-P. and M.R. The synthetic and UV/Vis spectroscopic work was performed by F.S. with support by M.A.T. and F.M. The Raman samples were prepared by A.H. and B.G.-L., the Raman measurements were performed and analyzed by B.G.-L., D.R. and F.B. The molecular structures were solved by F.S. and refined by A.H. The DFT calculations and NBO analyses were accomplished by A.H. The manuscript was written by F.S. and edited by S.H.-P. and A.H.

Funding: The authors gratefully acknowledge funding by the Deutsche Forschungsgemeinschaft (DFG) in the frame of the Priority Program 1740 "The Influence of Local Transport Processes on Chemical Reactions in Bubble Flows" (grant no. HE5480/10-1) and the FOR1405.

Conflicts of Interest: The authors declare no conflict of interest.

\section{References}

1. Punniyamurthy, T.; Velusamy, S.; Iqbal, J. Recent advances in transition metal catalyzed oxidation of organic substrates with molecular oxygen. Chem. Rev. 2005, 105, 2329-2363. [CrossRef] [PubMed]

2. Itoh, S.; Fukuzumi, S. Monooxygenase activity of type 3 copper proteins. Acc. Chem. Res. 2007, 40, 592-600. [CrossRef] [PubMed]

3. Yamazaki, S.-I.; Itoh, S. Kinetic evaluation of phenolase activity of tyrosinase using simplified catalytic reaction system. J. Am. Chem. Soc. 2003, 125, 13034-13035. [CrossRef] [PubMed]

4. Hamann, J.N.; Tuczek, F. New catalytic model systems of tyrosinase: Fine tuning of the reactivity with pyrazole-based N-donor ligands. Chem. Commun. 2014, 50, 2298-2300. [CrossRef] [PubMed]

5. Rolff, M.; Schottenheim, J.; Decker, H.; Tuczek, F. Copper- $\mathrm{O}_{2}$ reactivity of tyrosinase models towards external monophenolic substrates: Molecular mechanism and comparison with the enzyme. Chem. Soc. Rev. 2011, 40, 4077-4098. [CrossRef] [PubMed] 
6. Bijelic, A.; Pretzler, M.; Molitor, C.; Zekiri, F.; Rompel, A. The Structure of a Plant Tyrosinase from Walnut Leaves Reveals the Importance of "Substrate-Guiding Residues" for Enzymatic Specificity. Angew. Chem. Int. Ed. 2015, 54, 14677-14680. [CrossRef] [PubMed]

7. Matoba, Y.; Kumagai, T.; Yamamoto, A.; Yoshitsu, H.; Sugiyama, M. Crystallographic Evidence That the Dinuclear Copper Center of Tyrosinase Is Flexible during Catalysis. J. Biol. Chem. 2006, 281, 8981-8990. [CrossRef] [PubMed]

8. Mauracher, S.G.; Molitor, C.; Al-Oweini, R.; Kortz, U.; Rompel, A. Latent and active abPPO4 mushroom tyrosinase cocrystallized with hexatungstotellurate(VI) in a single crystal. Acta Crystallogr. D 2014, 70, 2301-2315. [CrossRef] [PubMed]

9. Herres-Pawlis, S.; Verma, P.; Haase, R.; Kang, P.; Lyons, C.T.; Wasinger, E.C.; Flörke, U.; Henkel, G.; Stack, T.D.P. Phenolate hydroxylation in a bis( $\mu$-oxo)dicopper(III) complex: Lessons from the guanidine/amine series. J. Am. Chem. Soc. 2009, 131, 1154-1169. [CrossRef] [PubMed]

10. Spada, A.; Palavicini, S.; Monzani, E.; Bubacco, L.; Casella, L. Trapping tyrosinase key active intermediate under turnover. Dalton Trans. 2009, 6468-6471. [CrossRef] [PubMed]

11. Hamann, J.N.; Herzigkeit, B.; Jurgeleit, R.; Tuczek, F. Small-molecule models of tyrosinase: From ligand hydroxylation to catalytic monooxygenation of external substrates. Coord. Chem. Rev. 2017, 334, 54-66. [CrossRef]

12. Elwell, C.E.; Gagnon, N.L.; Neisen, B.D.; Dhar, D.; Spaeth, A.D.; Yee, G.M.; Tolman, W.B. Copper-Oxygen Complexes Revisited: Structures, Spectroscopy, and Reactivity. Chem. Rev. 2017, 117, 2059-2107. [CrossRef] [PubMed]

13. Liebhäuser, P.; Hoffmann, A.; Herres-Pawlis, S. Tyrosinase Models: Synthesis, Spectroscopy, Theory, and Catalysis. In Reference Module in Chemistry, Molecular Sciences and Chemical Engineering; Elsevier: Waltham, MA, USA, 2016; p. 1. [CrossRef]

14. Mirica, L.M.; Ottenwaelder, X.; Stack, T.D.P. Structure and spectroscopy of copper-dioxygen complexes. Chem. Rev. 2004, 104, 1013-1045. [CrossRef] [PubMed]

15. Lewis, E.A.; Tolman, W.B. Reactivity of Dioxygen-Copper Systems. Chem. Rev. 2004, 104, 1047-1076. [CrossRef] [PubMed]

16. Cowley, R.E.; Tian, L.; Solomon, E.I. Mechanism of $\mathrm{O}_{2}$ activation and substrate hydroxylation in noncoupled binuclear copper monooxygenases. Proc. Natl. Acad. Sci. USA. 2016, 113, 12035-12040. [CrossRef] [PubMed]

17. Citek, C.; Lyons, C.T.; Wasinger, E.C.; Stack, T.D.P. Self-assembly of the oxy-tyrosinase core and the fundamental components of phenolic hydroxylation. Nat. Chem. 2012, 4, 317-322. [CrossRef] [PubMed]

18. Wendt, F.; Näther, C.; Tuczek, F. Tyrosinase and catechol oxidase activity of copper(I) complexes supported by imidazole-based ligands: Structure-reactivity correlations. J. Biol. Inorg. Chem. 2016, 21, 777-792. [CrossRef] [PubMed]

19. Wilfer, C.; Liebhäuser, P.; Hoffmann, A.; Erdmann, H.; Grossmann, O.; Runtsch, L.; Paffenholz, E.; Schepper, R.; Dick, R.; Bauer, M.; et al. Efficient Biomimetic Hydroxylation Catalysis with a Bis(pyrazolyl)imidazolylmethane Copper Peroxide Complex. Chem. Eur. J. 2015, 21, 17639-17649. [CrossRef] [PubMed]

20. Chiang, L.; Keown, W.; Citek, C.; Wasinger, E.C.; Stack, T.D.P. Simplest Monodentate Imidazole Stabilization of the oxy-Tyrosinase $\mathrm{Cu}_{2} \mathrm{O}_{2}$ Core: Phenolate Hydroxylation through a $\mathrm{Cu}(\mathrm{III})$ Intermediate. Angew. Chem. 2016, 128, 10609-10613. [CrossRef]

21. Schottenheim, J.; Fateeva, N.; Thimm, W.; Krahmer, J.; Tuczek, F. Catalytic Conversion of Monophenols to Ortho-Quinones in a Tyrosinase-Like Fashion: Towards More Biomimetic and More Efficient Model Systems. Z. Anorg. Allg. Chem. 2013, 639, 1491-1497. [CrossRef]

22. Réglier, M.; Jorand, C.; Waegell, B. Binuclear copper complex model of tyrosinase. J. Chem. Soc. Chem. Commun. 1990, 107, 1752-1755. [CrossRef]

23. Rolff, M.; Schottenheim, J.; Peters, G.; Tuczek, F. The first catalytic tyrosinase model system based on a mononuclear copper(I) complex: Kinetics and mechanism. Angew. Chem. Int. Ed. 2010, 49, 6438-6442. [CrossRef] [PubMed]

24. Becker, J.; Gupta, P.; Angersbach, F.; Tuczek, F.; Näther, C.; Holthausen, M.C.; Schindler, S. Selective Aromatic Hydroxylation with Dioxygen and Simple Copper Imine Complexes. Chem. Eur. J. 2015, 21, 11735-11744. [CrossRef] [PubMed] 
25. Wilfer, C.; Liebhäuser, P.; Erdmann, H.; Hoffmann, A.; Herres-Pawlis, S. Biomimetic Hydroxylation Catalysis Through Self-Assembly of a Bis(pyrazolyl)methane Copper-Peroxo Complex. Eur. J. Inorg. Chem. 2015, 2015, 494-502. [CrossRef]

26. Hamann, J.N.; Schneider, R.; Tuczek, F. Catalytic oxygenation of various monophenols by copper(I) complexes with bis(pyrazolyl)methane ligands: Differences in reactivity. J. Coord. Chem. 2015, 68, 3259-3271. [CrossRef]

27. Halfen, J.A.; Mahapatra, S.; Wilkinson, E.C.; Kaderli, S.; Young, V.G.; Que, L.; Zuberbühler, A.D.; Tolman, W.B. Reversible Cleavage and Formation of the Dioxygen O-O Bond Within a Dicopper Complex. Science 1996, 271, 1397-1400. [CrossRef] [PubMed]

28. Que, J.L.; Tolman, W.B. Bis( $\mu$-oxo)dimetal "Diamond" Cores in Copper and Iron Complexes Relevant to Biocatalysis. Angew. Chem. Int. Ed. 2002, 41, 1114-1137. [CrossRef]

29. Henson, M.J.; Mukherjee, P.; Root, D.E.; Stack, T.D.P.; Solomon, E.I. Spectroscopic and Electronic Structural Studies of the $\mathrm{Cu}(\mathrm{III}) 2$ Bis- $\mu$-oxo Core and Its Relation to the Side-On Peroxo-Bridged Dimer. J. Am. Chem. Soc. 1999, 121, 10332-10345. [CrossRef]

30. Schottenheim, J.; Gernert, C.; Herzigkeit, B.; Krahmer, J.; Tuczek, F. Catalytic Models of Tyrosinase: Reactivity Differences between Systems Based on Mono- and Binucleating Ligands. Eur. J. Inorg. Chem. 2015, 2015, 3501-3511. [CrossRef]

31. Herzigkeit, B.; Flöser, B.M.; Engesser, T.A.; Näther, C.; Tuczek, F. Tyrosinase Model Systems Supported by Pyrazolylmethylpyridine Ligands: Electronic and Steric Factors Influencing the Catalytic Activity and Impact of Complex Equilibria in Solution. Eur. J. Inorg. Chem. 2018, 2018, 3058-3069. [CrossRef]

32. Askari, M.S.; Esguerra, K.V.N.; Lumb, J.-P.; Ottenwaelder, X. A Biomimetic Mechanism for the Copper-Catalyzed Aerobic Oxygenation of 4-tert-Butylphenol. Inorg. Chem. 2015, 54, 8665-8672. [CrossRef] [PubMed]

33. Huang, Z.; Askari, M.S.; Esguerra, K.V.N.; Dai, T.-Y.; Kwon, O.; Ottenwaelder, X.; Lumb, J.-P. A bio-inspired synthesis of oxindoles by catalytic aerobic dual C-H functionalization of phenols. Chem. Sci. 2016, 7, 358-369. [CrossRef] [PubMed]

34. Esguerra, K.V.N.; Fall, Y.; Petitjean, L.; Lumb, J.-P. Controlling the catalytic aerobic oxidation of phenols. J. Am. Chem. Soc. 2014, 136, 7662-7668. [CrossRef] [PubMed]

35. Casella, L.; Gullotti, M.; Radaelli, R.; Di Gennaro, P. A tyrosinase model system. Phenol ortho-hydroxylation by a binuclear three-coordinate copper(I) complex and dioxygen. J. Chem. Soc. Chem. Commun. 1991, 1611. [CrossRef]

36. Garcia-Bosch, I.; Company, A.; Frisch, J.R.; Torrent-Sucarrat, M.; Cardellach, M.; Gamba, I.; Güell, M.; Casella, L.; Que, L.; Ribas, X.; et al. $\mathrm{O}_{2}$ activation and selective phenolate ortho hydroxylation by an unsymmetric dicopper $\mu-\eta^{1}: \eta^{1}$-peroxido complex. Angew. Chem. 2010, 122, 2456-2459. [CrossRef]

37. Hoffmann, A.; Citek, C.; Binder, S.; Goos, A.; Rübhausen, M.; Troeppner, O.; Ivanović-Burmazović, I.; Wasinger, E.C.; Stack, T.D.P.; Herres-Pawlis, S. Catalytic phenol hydroxylation with dioxygen: Extension of the tyrosinase mechanism beyond the protein matrix. Angew. Chem. Int. Ed. 2013, 52, 5398-5401. [CrossRef] [PubMed]

38. Liebhäuser, P.; Keisers, K.; Hoffmann, A.; Schnappinger, T.; Sommer, I.; Thoma, A.; Wilfer, C.; Schoch, R.; Stührenberg, K.; Bauer, M.; et al. Record Broken: A Copper Peroxide Complex with Enhanced Stability and Faster Hydroxylation Catalysis. Chem. Eur. J. 2017, 23, 12171-12183. [CrossRef] [PubMed]

39. Solem, E.; Tuczek, F.; Decker, H. Tyrosinase versus Catechol Oxidase: One Asparagine Makes the Difference. Angew. Chem. Int. Ed. 2016, 55, 2884-2888. [CrossRef] [PubMed]

40. Battaini, G.; Carolis, M.D.; Monzani, E.; Tuczek, F.; Casella, L. The phenol ortho-oxygenation by mononuclear copper(i) complexes requires a dinuclear $\mu-\eta^{2}: \eta^{2}$-peroxodicopper(II) complex rather than mononuclear $\mathrm{CuO}_{2}$ species. Chem. Commun. 2003, 726-727. [CrossRef]

41. Palavicini, S.; Granata, A.; Monzani, E.; Casella, L. Hydroxylation of phenolic compounds by a peroxodicopper(II) complex: Further insight into the mechanism of tyrosinase. J. Am. Chem. Soc. 2005, 127, 18031-18036. [CrossRef] [PubMed]

42. Bienemann, O.; Hoffmann, A.; Herres-Pawlis, S. (Guanidine)copper complexes: Structural variety and application in bioinorganic chemistry and catalysis. Rev. Inorg. Chem. 2011, 31, 83-108. [CrossRef] 
43. Schatz, M.; Raab, V.; Foxon, S.P.; Brehm, G.; Schneider, S.; Reiher, M.; Holthausen, M.C.; Sundermeyer, J.; Schindler, S. Combined spectroscopic and theoretical evidence for a persistent end-on copper superoxo complex. Angew. Chem. Int. Ed. 2004, 43, 4360-4363. [CrossRef] [PubMed]

44. Würtele, C.; Gaoutchenova, E.; Harms, K.; Holthausen, M.C.; Sundermeyer, J.; Schindler, S. Crystallographic characterization of a synthetic 1:1 end-on copper dioxygen adduct complex. Angew. Chem. Int. Ed. 2006, 45, 3867-3869. [CrossRef] [PubMed]

45. Maiti, D.; Lee, D.-H.; Gaoutchenova, K.; Würtele, C.; Holthausen, M.C.; Narducci Sarjeant, A.A.; Sundermeyer, J.; Schindler, S.; Karlin, K.D. Reactions of a copper(II) superoxo complex lead to C-H and $\mathrm{O}-\mathrm{H}$ substrate oxygenation: Modeling copper-monooxygenase $\mathrm{C}-\mathrm{H}$ hydroxylation. Angew. Chem. 2008, 120, 88-91. [CrossRef]

46. Wiesner, S.; Wagner, A.; Hübner, O.; Kaifer, E.; Himmel, H.-J. Thermochromism of Cu(I) Tetrakisguanidine Complexes: Reversible Activation of Metal-to-Ligand Charge-Transfer Bands. Chem. Eur. J. 2015, 21, 16494-16503. [CrossRef] [PubMed]

47. Wiesner, S.; Wagner, A.; Kaifer, E.; Himmel, H.-J. A Valence Tautomeric Dinuclear Copper Tetrakisguanidine Complex. Chem. Eur. J. 2016, 22, 10438-10445. [CrossRef] [PubMed]

48. Wiesner, S.; Wagner, A.; Kaifer, E.; Himmel, H.-J. The control of the electronic structure of dinuclear copper complexes of redox-active tetrakisguanidine ligands by the environment. Dalton Trans. 2016, 45, 15828-15839. [CrossRef] [PubMed]

49. Rösener, T.; Bienemann, O.; Sigl, K.; Schopp, N.; Schnitter, F.; Flörke, U.; Hoffmann, A.; Döring, A.; Kuckling, D.; Herres-Pawlis, S. A Comprehensive Study of Copper Guanidine Quinoline Complexes: Predicting the Activity of Catalysts in ATRP with DFT. Chem. Eur. J. 2016, 22, 13550-13562. [CrossRef] [PubMed]

50. Stanek, J.; Sackers, N.; Fink, F.; Paul, M.; Peters, L.; Grunzke, R.; Hoffmann, A.; Herres-Pawlis, S. Copper Guanidinoquinoline Complexes as Entatic State Models of Electron-Transfer Proteins. Chem. Eur. J. 2017, 23, 15738-15745. [CrossRef] [PubMed]

51. Dicke, B.; Hoffmann, A.; Stanek, J.; Rampp, M.S.; Grimm-Lebsanft, B.; Biebl, F.; Rukser, D.; Maerz, B.; Göries, D.; Naumova, M.; et al. Transferring the entatic-state principle to copper photochemistry. Nat. Chem. 2018, 10, 355-362. [CrossRef] [PubMed]

52. Herres-Pawlis, S.; Binder, S.; Eich, A.; Haase, R.; Schulz, B.; Wellenreuther, G.; Henkel, G.; Rübhausen, M.; Meyer-Klaucke, W. Stabilisation of a highly reactive bis( $\mu$-oxo)dicopper(III) species at room temperature by electronic and steric constraint of an unconventional nitrogen donor ligand. Chem. Eur. J. 2009, 15, 8678-8682. [CrossRef] [PubMed]

53. Herres-Pawlis, S.; Neuba, A.; Seewald, O.; Seshadri, T.; Egold, H.; Flörke, U.; Henkel, G. A Library of Peralkylated Bis-guanidine Ligands for Use in Biomimetic Coordination Chemistry. Eur. J. Org. Chem. 2005, 2005, 4879-4890. [CrossRef]

54. Herres, S.; Heuwing, A.J.; Flörke, U.; Schneider, J.; Henkel, G. Hydroxylation of a methyl group: Synthesis of $\left[\mathrm{Cu}^{2}(\mathrm{btmmO})_{2} \mathrm{I}\right]^{+}$and of $\left[\mathrm{Cu}_{2}(\mathrm{btmmO})_{2}\right]^{2+}$ containing the novel ligand \{bis(trimethylmethoxy)guanidino\}propane (btmmO) by copper-assisted oxygen activation. Inorg. Chim. Acta 2005, 358, 1089-1095. [CrossRef]

55. Hoffmann, A.; Wern, M.; Hoppe, T.; Witte, M.; Haase, R.; Liebhäuser, P.; Glatthaar, J.; Herres-Pawlis, S.; Schindler, S. Hand in Hand: Experimental and Theoretical Investigations into the Reactions of Copper(I) Mono- and Bis(guanidine) Complexes with Dioxygen. Eur. J. Inorg. Chem. 2016, 2016, 4744-4751. [CrossRef]

56. Strassl, F.; Grimm-Lebsanft, B.; Rukser, D.; Biebl, F.; Biednov, M.; Brett, C.; Timmermann, R.; Metz, F.; Hoffmann, A.; Rübhausen, M.; et al. Oxygen Activation by Copper Complexes with an Aromatic Bis(guanidine) Ligand. Eur. J. Inorg. Chem. 2017, 2017, 3350-3359. [CrossRef]

57. Bienemann, O.; Haase, R.; Jesser, A.; Beschnitt, T.; Döring, A.; Kuckling, D.; dos Santos Vieira, I.; Flörke, U.; Herres-Pawlis, S. Synthesis and Application of New Guanidine Copper Complexes in Atom Transfer Radical Polymerisation. Eur. J. Inorg. Chem. 2011, 2011, 2367-2379. [CrossRef]

58. Paul, M.; Strassl, F.; Hoffmann, A.; Hoffmann, M.; Schlüter, M.; Herres-Pawlis, S. Reaction Systems for Bubbly Flows. Eur. J. Inorg. Chem. 2018, 2018, 2101-2124. [CrossRef]

59. Schurr, D.; Strassl, F.; Liebhäuser, P.; Rinke, G.; Dittmeyer, R.; Herres-Pawlis, S. Decay kinetics of sensitive bioinorganic species in a SuperFocus mixer at ambient conditions. React. Chem. Eng. 2016, 1, 485-493. [CrossRef] 
60. Strassl, F.; Timmermann, J.; Schlüter, M.; Herres-Pawlis, S. Kinetics of the Activation of Oxygen. G.I.T. Lab. J. 2018, 22, 24-26.

61. Rohrmüller, M.; Hoffmann, A.; Thierfelder, C.; Herres-Pawlis, S.; Schmidt, W.G. The $\mathrm{Cu}_{2} \mathrm{O}_{2}$ torture track for a real-life system: $\mathrm{Cu}_{2}(\mathrm{btmgp})_{2} \mathrm{O}_{2}\left(2^{+}\right)$oxo and peroxo species in density functional calculations. J. Comput. Chem. 2015, 36, 1672-1685. [CrossRef] [PubMed]

62. Herres-Pawlis, S.; Flörke, U.; Henkel, G. Tuning of Copper(I)-Dioxygen Reactivity by Bis(guanidine) Ligands. Eur. J. Inorg. Chem. 2005, 2005, 3815-3824. [CrossRef]

63. Herres-Pawlis, S.; Berth, G.; Wiedemeier, V.; Schmidt, L.; Zrenner, A.; Warnecke, H.-J. Oxygen sensing by fluorescence quenching of [Cu(btmgp)I]. J. Lumin. 2010, 130, 1958-1962. [CrossRef]

64. Kantlehner, W.; Haug, E.; Mergen, W.W.; Speh, P.; Maier, T.; Kapassakalidis, J.J.; Bräuner, H.-J.; Hagen, H.; Orthoamide, X.L. Herstellung von 1,1,2,3,3-pentasubstituierten und 1,1,2,2,3,3-hexasubstituierten Guanidiniumsalzen sowie von 1,1,2,3,3-Pentaalkylguanidinen. Liebigs Ann. Chem. 1984, 1984, 108-126. [CrossRef]

65. Yang, L.; Powell, D.R.; Houser, R.P. Structural variation in copper(I) complexes with pyridylmethylamide ligands: Structural analysis with a new four-coordinate geometry index, $\tau_{4}$. Dalton Trans. 2007, 955-964. [CrossRef] [PubMed]

66. Raab, V.; Harms, K.; Sundermeyer, J.; Kovacevic, B.; Maksic, Z.B. 1,8-bis(dimethylethyleneguanidino) naphthalene: Tailoring the basicity of bisguanidine "proton sponges" by experiment and theory. J. Org. Chem. 2003, 68, 8790-8797. [CrossRef] [PubMed]

67. Herres-Pawlis, S.; Haase, R.; Verma, P.; Hoffmann, A.; Kang, P.; Stack, T.D.P. Formation of Hybrid Guanidine-Stabilized Bis( $\mu$-oxo)dicopper Cores in Solution: Electronic and Steric Perturbations. Eur. J. Inorg. Chem. 2015, 2015, 5426-5436. [CrossRef] [PubMed]

68. Dos Santos Vieira, I.; Herres-Pawlis, S. Lactide Polymerisation with Complexes of Neutral N-Donors-New Strategies for Robust Catalysts. Eur. J. Inorg. Chem. 2012, 2012, 765-774. [CrossRef]

69. Gherman, B.F.; Cramer, C.J. Quantum chemical studies of molecules incorporating a $\mathrm{Cu}_{2} \mathrm{O}_{2}{ }^{2+}$ core. Coord. Chem. Rev. 2009, 253, 723-753. [CrossRef]

70. Grimm-Lebsanft, B.; Brett, C.; Strassl, F.; Rukser, D.; Biednov, M.; Biebl, F.; Naumova, M.; Hoffmann, A.; Akinsinde, L.; Brückner, D.; et al. A cryostat for low temperature resonance Raman measurements on operando oxygenated bioinorganic model complexes. Inorg. Chim. Acta 2017, 481, 176-180. [CrossRef]

71. Karlin, K.D.; Itoh, S. Copper-Oxygen Chemistry; Wiley: Hoboken, NJ, USA, 2011.

72. Hoffmann, A.; Herres-Pawlis, S. Theoretical Studies on Tyrosinase Models. In Encyclopedia of Inorganic and Bioinorganic Chemistry; Scott, R.A., Ed.; John Wiley \& Sons, Ltd.: Chichester, UK, 2011; pp. 1-15.

73. Weinhold, F.; Landis, C.R. Valency and Bonding; Cambridge University Press: Cambridge, UK, 2005.

74. Glendening, E.D.; Landis, C.R.; Weinhold, F. NBO 6.0: Natural bond orbital analysis program. J. Comput. Chem. 2013, 34, 1429-1437. [CrossRef] [PubMed]

75. Glendening, E.D.; Badenhoop, J.K.; Reed, A.E.; Carpenter, J.E.; Bohmann, J.A.; Morales, C.M.; Landis, C.R.; Weinhold, F. NBO 6.0.; Theoretical Chemistry Institute, University of Wisconsin: Madison, WI, USA, 2013.

76. Tao, J.; Perdew, J.P.; Staroverov, V.N.; Scuseria, G.E. Climbing the Density Functional Ladder: Nonempirical Meta-Generalized Gradient Approximation Designed for Molecules and Solids. Phys. Rev. Lett. 2003, 91, 146401-1-146401-4. [CrossRef] [PubMed]

77. Weigend, F.; Ahlrichs, R. Balanced basis sets of split valence, triple zeta valence and quadruple zeta valence quality for H to Rn: Design and assessment of accuracy. Phys. Chem. Chem. Phys. 2005, 7, 3297-3305. [CrossRef] [PubMed]

78. Goerigk, L.; Grimme, S. A thorough benchmark of density functional methods for general main group thermochemistry, kinetics, and noncovalent interactions. Phys. Chem. Chem. Phys. 2011, 13, 6670-6688. [CrossRef] [PubMed]

79. Grimme, S.; Ehrlich, S.; Goerigk, L. Effect of the damping function in dispersion corrected density functional theory. J. Comput. Chem. 2011, 32, 1456-1465. [CrossRef] [PubMed]

80. Rohrmüller, M.; Herres-Pawlis, S.; Witte, M.; Schmidt, W.G. Bis- $\mu$-oxo and $\mu-\eta^{2}: \eta^{2}$-peroxo dicopper complexes studied within (time-dependent) density-functional and many-body perturbation theory. J. Comput. Chem. 2013, 34, 1035-1045. [CrossRef] [PubMed]

81. Hoffmann, A.; Herres-Pawlis, S. Donor-driven conformational flexibility in a real-life catalytic dicopper(II) peroxo complex. Phys. Chem. Chem. Phys. 2016, 18, 6430-6440. [CrossRef] [PubMed] 
82. Huber, S.M.; Ertem, M.Z.; Aquilante, F.; Gagliardi, L.; Tolman, W.B.; Cramer, C.J. Generating $\mathrm{Cu}(\mathrm{II})$-oxyl $/ \mathrm{Cu}(\mathrm{III})$-oxo species from $\mathrm{Cu}(\mathrm{I})$ - $\alpha$-ketocarboxylate complexes and $\mathrm{O}_{2}$ : In silico studies on ligand effects and C-H-activation reactivity. Chem. Eur. J. 2009, 15, 4886-4895. [CrossRef] [PubMed]

83. Teuber, H.-J.; Benz, S. Reaktionen mit Nitrosodisulfonat, XXXIV. Chinolin-chinone-(7.8). Chem. Ber. 1967, 100, 2077-2092. [CrossRef]

84. SMART (Version 5.631); Bruker AXS Inc.: Madison, WI, USA.

85. SAINT and SADABS; Bruker AXS Inc.: Madison, WI, USA, 2008.

86. XPREP; Bruker AXS Inc.: Madison, WI, USA, 2007.

87. Sheldrick, G.M. Phase annealing in SHELX-90: Direct methods for larger structures. Acta Crystallogr. A 1990, 46, 467-473. [CrossRef]

88. Hübschle, C.B.; Sheldrick, G.M.; Dittrich, B. ShelXle: A Qt graphical user interface for SHELXL. J. Appl. Crystallogr. 2011, 44, 1281-1284. [CrossRef] [PubMed]

89. Spek, A.L. PLATON, A Multipurpose Crystallographic Tool; Utrecht University: Utrecht, The Netherlands, 2008.

90. Spek, A.L. Structure validation in chemical crystallography. Acta Crystallogr. D 2009, 65, 148-155. [CrossRef] [PubMed]

91. Schulz, B.; Bäckström, J.; Budelmann, D.; Maeser, R.; Rübhausen, M.; Klein, M.V.; Schoeffel, E.; Mihill, A.; Yoon, S. Fully reflective deep ultraviolet to near infrared spectrometer and entrance optics for resonance Raman spectroscopy. Rev. Sci. Instrum. 2005, 76, 73107. [CrossRef]

92. Frisch, M.J.; Trucks, G.W.; Schlegel, H.B.; Scuseria, G.E.; Robb, M.A.; Cheeseman, J.R.; Scalmani, G.; Barone, V.; Petersson, G.A.; Nakatsuji, H.; et al. Gaussian 16 Rev. B.01; Gaussian. Inc.: Wallingford, CT, USA, 2016.

93. Hoffmann, A.; Grunzke, R.; Herres-Pawlis, S. Insights into the influence of dispersion correction in the theoretical treatment of guanidine-quinoline copper(I) complexes. J. Comput. Chem. 2014, 35, 1943-1950. [CrossRef] [PubMed]

(C) 2018 by the authors. Licensee MDPI, Basel, Switzerland. This article is an open access article distributed under the terms and conditions of the Creative Commons Attribution (CC BY) license (http://creativecommons.org/licenses/by/4.0/). 